\title{
Temporal Changes in Ozone Concentrations and Their Impact on Vegetation
}

\author{
Stanislav Jurán̆ ${ }^{1, *}$, John Grace ${ }^{1,2}$ and Otmar Urban ${ }^{1}$ (D) \\ 1 Global Change Research Institute, Czech Academy of Sciences, Bělidla 986/4a, \\ 60300 Brno, Czech Republic; j.grace@ed.ac.uk (J.G.); urban.o@czechglobe.cz (O.U.) \\ 2 School of GeoSciences, University of Edinburgh, Crew Bldg, Kings Bldgs, Alexander Crum Brown Rd, \\ Edinburgh EH9 3FF, UK \\ * Correspondence: juran.s@czechglobe.cz
}

Citation: Juráň, S.; Grace, J.; Urban,

O. Temporal Changes in Ozone

Concentrations and Their Impact on Vegetation. Atmosphere 2021, 12, 82. https://doi.org/10.3390/

atmos12010082

Received: 4 December 2020

Accepted: 3 January 2021

Published: 7 January 2021

Publisher's Note: MDPI stays neutral with regard to jurisdictional clai$\mathrm{ms}$ in published maps and institutional affiliations.

Copyright: $\odot 2021$ by the authors. Licensee MDPI, Basel, Switzerland. This article is an open access article distributed under the terms and conditions of the Creative Commons Attribution (CC BY) license (https:// creativecommons.org/licenses/by/ $4.0 /)$.

\begin{abstract}
Tropospheric concentrations of phytotoxic ozone $\left(\mathrm{O}_{3}\right)$ have undergone a great increase from preindustrial 10-15 ppbv to a present-day concentration of 35-40 ppbv in large parts of the industrialised world due to increased emissions of $\mathrm{O}_{3}$ precursors including $\mathrm{NO}_{\mathbf{x}}, \mathrm{CO}, \mathrm{CH}_{4}$ and volatile organic compounds. The rate of increase in $\mathrm{O}_{3}$ concentration ranges between 1 ppbv per decade in remote locations of the Southern hemisphere and 5 ppbv per decade in the Northern hemisphere, where largest sources of $\mathrm{O}_{3}$ precursors are located. Molecules of $\mathrm{O}_{3}$ penetrating into the leaves through the stomatal apertures trigger the formation of reactive oxygen species, leading thus to the damage of the photosynthetic apparatus. Accordingly, it is assumed, that $\mathrm{O}_{3}$ increase reduces the terrestrial carbon uptake relative to the preindustrial era. Here we summarise the results of previous manipulative experiments in laboratory growth cabinets, field open-top chambers and free-air systems together with $\mathrm{O}_{3}$ flux measurements under natural growth conditions. In particular, we focus on leaf-level physiological responses in trees, variability in stomatal $\mathrm{O}_{3}$ flux and changes in carbon fluxes and biomass production in forest stands. As the results reported in the literature are highly variable, ranging from negligible to severe declines in photosynthetic carbon uptake, we also discuss the possible interactions of $\mathrm{O}_{3}$ with other environmental factors including solar radiation, drought, temperature and nitrogen deposition. Those factors were found to have great potential to modulate stomata openness and $\mathrm{O}_{3}$ fluxes.
\end{abstract}

Keywords: carbon uptake; manipulation experiment; interaction effect; tropospheric ozone; stomatal ozone flux

\section{Changes in $\mathrm{O}_{3}$ Concentration}

Concentrations of $\mathrm{O}_{3}\left(\left[\mathrm{O}_{3}\right]\right)$ have been increasing since the preindustrial era due to an increase of its precursors [1]. As an important secondary phytotoxic air pollutant causing injury to plant tissue and a significant decrease of crop and timber yield, it deserves attention from farmers, scientists and the general public. Although the historical $\left[\mathrm{O}_{3}\right]$ are unreliable because of a limited number of observations and disagreements in the retrospective modelling [2], it is considered that $\left[\mathrm{O}_{3}\right]$ has increased from the baseline of 10-15 ppbv (parts per billion per volume, volume mixing ratio; [3]) to current concentrations of 35-40 ppbv in large parts of the industrialised world [4,5]). Plant species vary in their sensitivity to $\left[\mathrm{O}_{3}\right]$, and it seems that genetically based detoxification processes [6] are significant and certainly sufficient to protect plants against any harmful effect of low pre-industrial $\left[\mathrm{O}_{3}\right]$. The concept of "effective $\mathrm{O}_{3}$ flux", defined as a balance between stomatal $\mathrm{O}_{3}$ flux and detoxifying capacity of the plant, was proposed [7]. However, there is a huge variety of clones and cultivars (poplars, beans, etc.), which are sensitive even to low $\left[\mathrm{O}_{3}\right]$, demonstrating a strong genetic basis for plant sensitivity to $\mathrm{O}_{3}$. 
Ozone was discovered in 1839 by Christian Friedrich Schönbein during his experiments with the electrolysis of water. At the start of the modern era, $\left[\mathrm{O}_{3}\right]$ was measured using classical procedures involving titration. In Europe, one of the first measurements was performed by Albert-Lévy in Paris. He showed $\left[\mathrm{O}_{3}\right]$ to be $11 \pm 2 \mathrm{ppbv}$ over the period 1876-1910 [8]. Even in high elevations, at Pic du Midi, France, 3000 m a.s.l., a concentration of only $10 \mathrm{ppbv}$ was measured during 1874-1895 with a peak in spring and a minimum in winter [9]. The oldest continuous measurements started at the ArkonaZingst site (Germany) in 1956: they showed $\left[\mathrm{O}_{3}\right]$ in the 1950s-1960s to be in the range of 15-20 ppbv [10].

The first harmful effects of $\mathrm{O}_{3}$ were reported in the San Bernardino Mountains of Southern California, in Pinus ponderosa forest [11]. During the 1970s, in inland valleys around Los Angeles, maximum annual $\left[\mathrm{O}_{3}\right]$ reaching 300-400 ppbv was common [12]. Air pollution led to an increase in the number of days with $\left[\mathrm{O}_{3}\right]>95 \mathrm{ppbv}$ from 114 in 1963 to 163 days in 1978 [13].

Elsewhere, an increase of 2-4 ppbv per decade was later reported [4], and an increase of $0.35 \mathrm{ppbv}$ per year was seen in South Korea and Japan in 2000-2014 [14,15]. However, at highly polluted urban sites the increase was rapid, 2.6 ppbv per year in Beijing in 2005-2011 [16] and 2 ppbv per year in the Pearl River Delta region [17]. Recently, interannual and decadal changes are reported elsewhere: in the North China plains, there were increases of 3-5 ppbv (2001-2006), mostly attributed to a change of cloud cover and temperature [18] with only a low impact $(1-2 \%)$ due to afforestation and increased VOC production [19].

In the southern hemisphere, with much less land area and industry, there is a trend of an increasing $\left[\mathrm{O}_{3}\right]$ of $0.1 \mathrm{ppbv}$ per year from 1990-2015 ranging from 0.04 at Baring head (New Zealand) to 0.21 at Arrival Heights (Antarctica). Overall there seems to be a concentration increase towards southern latitudes [20]. Similarly, an increase of $0.66 \mathrm{ppbv}$ per decade has been observed in Chile at El Tololo mountain [21]. The increase is attributed to the poleward expansion of the Hadley Circulation, bringing the $\mathrm{O}_{3}$-rich air from the stratosphere [20].

Marked diurnal courses of $\left[\mathrm{O}_{3}\right]$ have usually been found, particularly in large urban agglomerations [22]. $\mathrm{O}_{3}$ is produced over the day, associated with high UV irradiance which drives the photochemistry, whilst at the same time, $\mathrm{O}_{3}$ is being removed by wet and dry depositions on various surfaces and uptake by plants. Typically, $\mathrm{NO}_{\mathrm{x}}$ is transported from urban areas at low elevations to rural forested areas where significant amounts of VOC are being produced as natural plant emissions. Thus the appropriate $\mathrm{VOC} / \mathrm{NO}_{\mathrm{x}}$ ratio for $\mathrm{O}_{3}$ production, ranging between 4 and 15, is achieved [23]. Such middle-range transport of $\mathrm{NO}_{\mathrm{x}}$ is responsible for the enhanced production of $\mathrm{O}_{3}$ in rural areas, often at high elevations, and may result in damage of vegetation. A globally averaged lifetime of tropospheric $\mathrm{O}_{3}$ is approximately 23 days [24]. Therefore, $\mathrm{O}_{3}$ could be transported even at long-range between continents [25]. However, its lifetime inside the boundary layer is much shorter because of the surface deposition and chemical reactions, such as reduction of $\mathrm{O}_{3}$ to oxygen. These processes, as well as the spatio-temporal heterogeneity in $\left[\mathrm{O}_{3}\right]$, are further modulated by the seasonal variability of microclimatic conditions (Figure 1).

At nightfall $\left[\mathrm{O}_{3}\right]$ rapidly decreases because of the oxidation of $\mathrm{NO}$ to $\mathrm{NO}_{2}$ in the absence of production. Distinct seasonal behaviour patterns have been reported in industrialised and rural areas of Europe and the USA: (1) a broad spring-summer maximum of $\left[\mathrm{O}_{3}\right]$ in the industrialised parts, but (2) a minimum $\left[\mathrm{O}_{3}\right]$ in summer and autumn in remote regions [26]. Noticeably, spring $\left[\mathrm{O}_{3}\right]$ maximum is a northern hemispheric phenomenon, only found in northern and western parts of Europe. In the temperate zone of Central and Eastern Europe, the highest $\left[\mathrm{O}_{3}\right]$ are observed in summer months when temperatures and irradiances reach their highest values (reviewed in Monks [27]), while these are lowest in winter $[28,29]$. Moreover, substantially higher $\left[\mathrm{O}_{3}\right]$ are observed under clear skies than under cloudy skies, but not in winter [29]. 
High $\mathrm{O}_{3}$ concentration

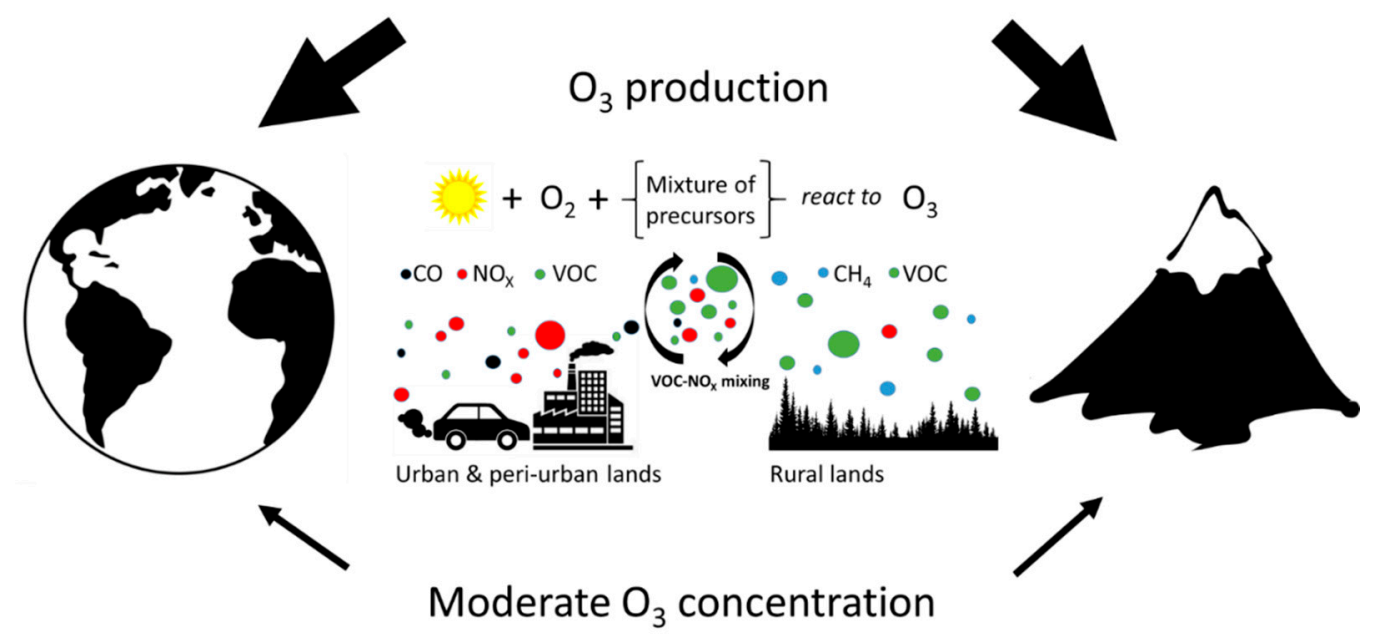

Figure 1. Scheme of tropospheric ozone $\left(\mathrm{O}_{3}\right)$ formation. Tropospheric ozone is formed in a complex series of photochemical reactions driven by ultraviolet (UV) solar radiation. $\mathrm{NO}_{2}$ is photolyzed to form $\mathrm{NO}$ and an electronically excited oxygen atom, $\mathrm{O}$, which reacts with molecular oxygen in the atmosphere $\left(\mathrm{O}_{2}\right)$ to form $\mathrm{O}_{3}$. However, $\mathrm{O}_{3}$ may also regenerate $\mathrm{NO}_{2}$ in the presence of $\mathrm{NO}$, thus keeping a photo-stationary state. Therefore, net $\mathrm{O}_{3}$ production occurs when $\mathrm{O}_{3}$ precursors, such as carbon monoxide $(\mathrm{CO})$, methane $\left(\mathrm{CH}_{4}\right)$ and volatile organic compounds (VOCs), are present in the atmosphere at appropriate concentrations. This chain of photochemical reactions is catalysed by hydroxide anion $\left(\mathrm{OH}^{-}\right)$, hydroperoxyl radical $\left(\mathrm{HO}_{2}\right), \mathrm{NO}$ and $\mathrm{NO}_{2}$. Enhanced $\mathrm{O}_{3}$ production thus occurs under high levels of UV radiation and when the concentration of precursors reaches critical levels. Transport of precursors and catalysts from urban and industrial lands $\left(\mathrm{CO}, \mathrm{NO}_{\mathrm{x}}\right.$ and $\mathrm{VOC}$ ) to rural conditions enhances mixing of polluted air plumes with clean rural air (enriched with $\mathrm{CH}_{4}$ and $\mathrm{VOC}$ ) and results in a $\mathrm{VOC} / \mathrm{NO}_{\mathrm{x}}$ ratio conducive for $\mathrm{O}_{3}$ formation. Therefore, latitudinal and elevational distribution differences in $\mathrm{O}_{3}$ concentration are likely caused by the distribution of $\mathrm{O}_{3}$ precursor sources associated with industrialization development and/or by an elevational increase in UV radiation.

In the Czech Republic, Central Europe, the annual maxima of $\left[\mathrm{O}_{3}\right]$ are being shifted towards the later parts of the year. The $\left[\mathrm{O}_{3}\right]$ peak has shifted from Day of Year (DOY) $120-170$ at the beginning of the millennium towards DOY 160-175 over the following 20 years depending on the locality [30]. The shift is probably caused by the change of meteorological conditions towards warmer and dryer years with consequently more favourable conditions for $\mathrm{O}_{3}$ formation [30]. However, contradicting results are found in the summer monsoon climate of Beijing: $\left[\mathrm{O}_{3}\right]$ maximum is in June, while the lowest values of $\left[\mathrm{O}_{3}\right]$ are in December [31]. Similarly, in the Yangtze River Delta, the maximum is found in July with a second maximum in September, followed by a minimum in November [32]. At 38 sites involved in the European Monitoring and Evaluation Programme (EMEP), there was a decrease of $\left[\mathrm{O}_{3}\right]$ reported in the 1990s, however later, around 2000, the $\left[\mathrm{O}_{3}\right]$ had increased; then, in the 2010s it decreased [33]. Interpretation of the trends and spatial patterns over several past decades has been challenging [34]; however in Europe, because of the successfully adopted measures to reduce $\mathrm{O}_{3}$ precursors, $\mathrm{O}_{3}$ surface concentration decreased by $2 \%$ from 2000 to 2014 [35].

In the Arctic, there is no clear trend in Barrow (USA, Alaska, 1981-2010) and Resolute (Canada), although there is an increasing trend in short-term periods [36]. In the southern hemisphere, the strongest increase in $\left[\mathrm{O}_{3}\right]$ is reported to be during the austral autumn (March-May) with an increase of $0.14 \mathrm{ppbv}$ per year on average, while in other seasons the increase is only $0.07-0.12 \mathrm{ppbv}$ per year [20]. The exception is South Africa with a sharp increase of $1 \mathrm{ppbv}$ per year over the period 1992-2011 [37]. An overview of $\left[\mathrm{O}_{3}\right]$ in different regions of the world, with model predictions for the future, is given by Archibald et al. [5]. 
Currently, $\left[\mathrm{O}_{3}\right]$ and its changes are both measured and modelled, however modelling approaches based on state-of-the-art models may suffer from huge uncertainties [38], and some are unable to track accurately $\left[\mathrm{O}_{3}\right]$ from the past.

\section{Methodological Approaches}

The earliest attempts to examine the response of plants to ozone were conducted in glasshouses, growth rooms or transparent enclosures with air-conditioning [39-41]. These studies were short-term, and often focused on foliar damage, rather than growth or physiology. Over several decades, researchers have moved away from this starting point in an effort to achieve realism and understanding (Figure 2).

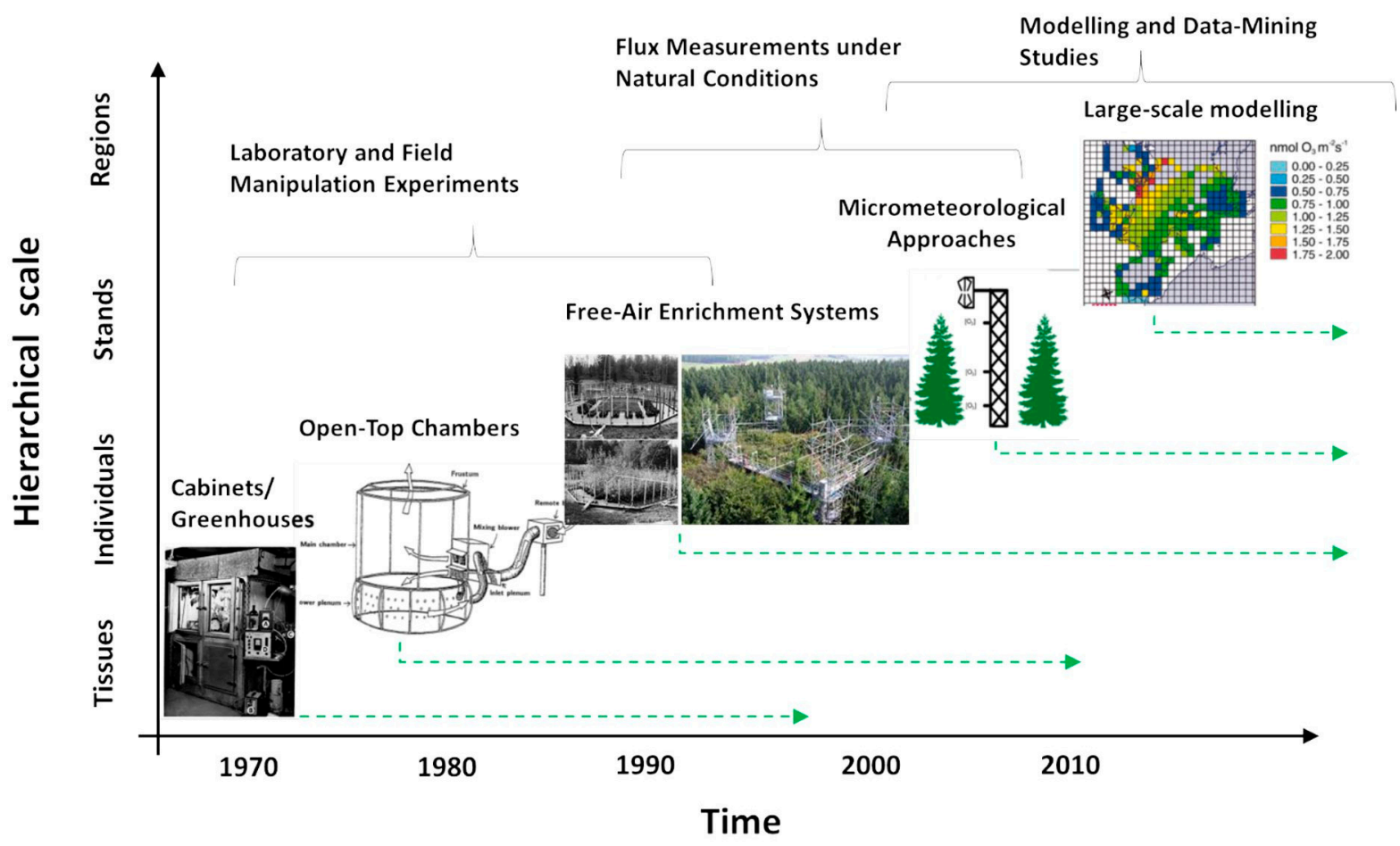

Figure 2. The scheme suggests a time development of methodological approaches applied to examine the plant responses to $\mathrm{O}_{3}$ in relation to a transition from tissue-level studies, through studies at the level of individuals and stands, up to large-scale modelling.

\subsection{Open-Top Chambers}

Soon, methods for quantifying the long-term growth-responses of plants to atmospheric pollutants $\left(\mathrm{SO}_{2}, \mathrm{O}_{3}\right.$, acid mist) were being developed. From early 1970s researchers began to employ open-top chambers (OTCs), each consisting of a transparent plastic structure, often a cylinder, into which a prepared gas mixture could be injected [42,43]. The 'open top' enabled mixing of the chamber air with the ambient air in an attempt to aid mixing and reduce unwanted microclimatological effects, particularly heating, that might occur in a fully closed chamber. OTCs became widely used, not only for pollutants such as $\mathrm{O}_{3}$ and $\mathrm{SO}_{2}$ but also to explore the impact of rising $\mathrm{CO}_{2}$ on plant growth. Features of their designs are illustrated in retrospective reviews by Allen et al. [44] and D'Andrea and Rinaldi [45].

However, it was realised that a distinct microclimate would inevitably develop inside the OTC, with higher temperature and humidity than outside, and a lower wind speed and precipitation. The temperature difference was found to be typically less than two degrees [46]. Differences in humidity were likely to influence stomatal conductance, and the lack of plant movement in the natural wind might influence the thigmo-morphogenic response [47]. For many purposes, small differences in environmental variables may not 
matter, as both control and treatment chambers induce the same conditions. On the other hand, plant responses to pollutant levels may well be different when the environmental variables are changed, and extrapolation to present-day ambient conditions may thus be unwise. Another issue is the non-uniform distribution of gas within the chamber. Wind tunnel models were constructed to aid design [48,49], and analysis was made of gaseous diffusion pathways [50]. It was found that the addition of a frustum at the top edge of the chamber prevented large incursions of ambient air in windy conditions, and also economised on the use of the pollutant gas. Attention was given to the points of entry of gas to the chamber. Leaves in the 'near field' of the entering gas would receive an unwanted high dosage unless the entry points are well distributed [51]. When the pollutant gas is ozone, this may be a special problem. To distribute the injected gas, many designs featured one or two toroidal ("dough-nut") perforated gas exchange units made of flexible polythene, and sometimes a fan was fitted.

Despite these difficulties, OTCs have been widely used. They have the great advantage of being relatively inexpensive, and therefore a number of them can be deployed in an experimental design which includes appropriate replication. Plants may be rooted in native soil, thus minimising the unwanted effects of root restriction usually seen in pot-grown plants in glasshouses or growth-rooms. Moreover, the environment inside the OTC moreor-less follows the outside environment and thus plants experience almost natural photon irradiance, photoperiods and seasonality. Further, they have been used successfully in many outdoor settings: for field crops [52], for trees [53] and for natural ecosystems [54]. As knowledge progresses, researchers have been able to use OTCs in new and imaginative ways, for example, to investigate the important interactions of $\mathrm{O}_{3}$ pollution with nitrogen supply [55], to investigate competition between species in different $\mathrm{O}_{3}$ scenarios [56,57] and to study the impact of $\mathrm{O}_{3}$ on root growth and development [58].

\subsection{Free-Air Systems}

The next step was the development of fumigation systems without chambers $[59,60]$. In most of the early work, the main interest was $\mathrm{SO}_{2}$ and the system was known as the freeair controlled enrichment system (FACE). Later, when used by the $\mathrm{CO}_{2}$ research community this became free-air $\mathrm{CO}_{2}$ enrichment (also FACE). There are no walls or barriers; the gas is distributed to the open air from a circle of towers and the rate is controlled so that the concentrations at the canopy level are constant [61]. The installation and running costs are relatively high, and the degree of replication is usually limited by the funds or area of land available for the project. FACE experiments using $\mathrm{O}_{3}$ have now been used many times, particularly on crop species and young trees [62-64]. In some of these experiments, more than one gas may be used to examine the interactions, particularly between $\mathrm{O}_{3}$ and $\mathrm{CO}_{2}[62,65,66]$.

FACE rings may be quite small (diameter just a few metres) for use with short vegetation [56] or huge (diameter $35 \mathrm{~m}$ ) for mature forests [67]. To obtain meaningful results, experiments may be conducted for just one growing season in the case of annual crops, or they may be extended for many years in the case of forests [68]. Where such major facilities are established, it becomes desirable and highly effective to include eco-physiological experiments, including both above- and below-ground components [69].

For trees, there has been a preponderance of work on seedlings and saplings. For mature trees, the scale of construction, both for OTCs and FACE rings, is often beyond the funding capabilities. Where two gases are involved, 12 units would seem to be the minimum (see the experimental design of Isebrands et al. [62]). Seedlings and saplings inevitably have different growth responses from mature trees and cannot ever be a realistic surrogate for them [70,71]. Likewise, in studies on trees, there is a tendency to work on fast-growing species, which may not be representative of the world's forests. 


\subsection{Micrometeorological Approaches}

With the rapid adoption of micrometeorological techniques, particularly eddy-covariance, it became possible to measure directly the flux of trace gases to vegetation. Eddy-covariance requires sensors that respond quickly to concentration changes with a frequency of several $\mathrm{Hz}$. For the case of $\mathrm{O}_{3}$, the gas could be measured by chemiluminescence and such sensors were developed very early [72,73]. Fast sensors for $\mathrm{CO}_{2}$ and $\mathrm{H}_{2} \mathrm{O}$, and their use to measure $\mathrm{CO}_{2}$ fluxes came about a decade later [74]. This opened up new possibilities to utilise the

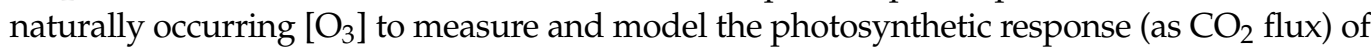
mature vegetation to episodes of pollution. This line of research is expected to provide an understanding of exactly how the fundamental ecophysiology of the plant responds to the wildly varying $\left[\mathrm{O}_{3}\right]$, and how this response depends on hourly, daily or seasonal changes in natural conditions by interrogating a long time-series (preferably over several years).

As there are several hundred long-established and well-maintained $\mathrm{CO}_{2}$ flux stations in the world $[75,76]$, it would seem to be a simple matter to add $\mathrm{O}_{3}$ sensors to those stations that measure trace gases and the flux of water vapor and heat [77-79]. Usually, the water vapor fluxes are used in conjunction with other variables to estimate the stomatal conductance of the canopy, and thus it has been possible to partition the overall flux of $\mathrm{O}_{3}$ into stomatal and non-stomatal components. The non-stomatal components of the flux are unlikely to influence the plant's physiology directly: they include deposition to inert surfaces and reaction with gaseous compounds in the canopy air-space.

It has been found that $\mathrm{O}_{3}$ uptake by plant canopies is greatest when the $\mathrm{CO}_{2}$ uptake and stomatal conductance to $\mathrm{O}_{3}$ are maximal [78,80-83]. Moreover, the photosynthetic uptake of $\mathrm{CO}_{2}$ is more strongly related to the stomatal conductance to ozone than simply to $\left[\mathrm{O}_{3}\right][28,70,84,85]$. In a more recent paper, Juráň et al. [29] show how diffuse sky conditions are associated with higher stomatal uptake of $\mathrm{O}_{3}$ even though the concentrations of ozone are higher in clear sky conditions. The likely explanation of the diffuse-sky effect is that meteorological conditions are more humid under diffuse skies and thus stomata are more open because of the well-established stomatal response to vapor pressure deficit (VPD; [84]).

A full analysis of the effect of $\mathrm{O}_{3}$ on $\mathrm{CO}_{2}$ flux from micrometeorological data is however beset with difficulties because the climatological variables are strongly intercorrelated. In particular, solar radiation is responsible for the photochemical production of $\mathrm{O}_{3}$ as well as for photosynthesis. Fares et al. [85] tried to overcome the confounding effect by first fitting a simple relationship between solar radiation and $\mathrm{CO}_{2}$ flux, and thereafter examining the effect of $\mathrm{O}_{3}$ on the residuals of this relationship. There is scope for the development of a standardised suite of statistical tools to identify the optimal methodology for data-mining in this important area.

\subsection{Modelling Approaches}

How should this wealth of research data, experimental and observational, be modelled to enable upscaling? The first approach is to develop mechanistic models. Modelling the uptake of gases by leaf canopies using the basic principle of an Ohm's Law resistance network was developed by Monteith and others in the 1960s in relation to $\mathrm{CO}_{2}$ and water vapor and is widely applied at scales from leaf to landscape $[86,87]$. The same type of model, with certain modifications, might be used to simulate the effect of $\mathrm{O}_{3}$ on $\mathrm{CO}_{2}$ uptake. The resistance network needs to allow for the uptake through stomatal and non-stomatal pathways [88], and a robust stomatal model is required that can respond to environmental variables [89]. The important and more difficult step is to go beyond modelling uptake, towards modelling the effective dose of $\mathrm{O}_{3}$. Ideally, this would require knowledge of the species-dependent internal defences (detoxification) of the leaf tissues. The effective ozone dose is then the difference between the integrated uptake by the stomata and the integrated detoxification rate. 
The second modelling approach is the application of machine-learning methods with artificial neural networks, ANN [90]. Prediction using ANN is widely used in industry and has been successfully applied to model $\mathrm{CO}_{2}$ fluxes [91-93]. It requires large data sets, so that all combinations of environmental variables are represented. Savi et al. [90] demonstrated the efficacy of the approach applied to model $\mathrm{O}_{3}$ uptake by analysis of flux data from 11 sites of diverse ecosystem types and locations from the north to the south of Europe. They found the reduction in net ecosystem productivity caused by $\mathrm{O}_{3}$ was highly site-specific and varied 0 to 2.6 percent.

To address the policy issues regarding pollution control, models need to be at regional or even global scale ("upscaling"). This has been tried by [89,94,95]. For example, Oliver et al. [89] adapted the UK's JULES model by incorporating data-based assumptions about the threshold ozone uptake required to reduce photosynthesis. They found rather little data on dose-response relationships; however, they made reasonable assumptions about the different sensitivity of different plant functional types (PFTs). The model was run for the whole of Europe in the period 1901-2050. $\mathrm{O}_{3}$ was found to reduce the gross primary productivity (GPP) by 4-9 percent and carbon was lost from the soil. Boreal regions suffered less than temperate regions.

\section{Effect on Carbon Uptake from Leaf to Ecosystem Level}

In the atmosphere, $\mathrm{O}_{3}$ is known to react with double bonds between carbon atoms to produce aldehydes, ketones or higher oxidised molecules - that has been known since 1840 when $\mathrm{O}_{3}$ was discovered. The mechanism is the same in plants, where, after penetrating through the stomatal apertures, ozone molecules oxidise the fatty acids of cell/organelle membranes; this leads to the formation of reactive oxygen species (ROS) causing damage of tissues (Figure 3). Such damage to photosynthetic membranes, despite the plant's increased defensive production of ROS scavenging enzymes ascorbate [96] and compounds with antioxidative capacity (carotenoids; $[97,98]$ ), inevitably leads to local necrotic cell death or early senescence [99]. Among others, Luwe and Heber [6] have shown that elevated $\left[\mathrm{O}_{3}\right]$ increases concentrations of reduced and oxidised forms of ascorbate in the apoplast of leaves of different plant species. These transient increases are, however, often insufficient to protect leaf tissues. The yellowish mottling occurs particularly close to stomata and appears more often in older than young leaves [100]. Microscopic studies identified enlargement of intercellular space and chloroplast injuries, including thylakoid swellings and membrane disruption, as typical symptoms of $\mathrm{O}_{3}$ impact [97]. Such reduced photosynthetically active leaf area leads to a reduced carbon uptake [101].

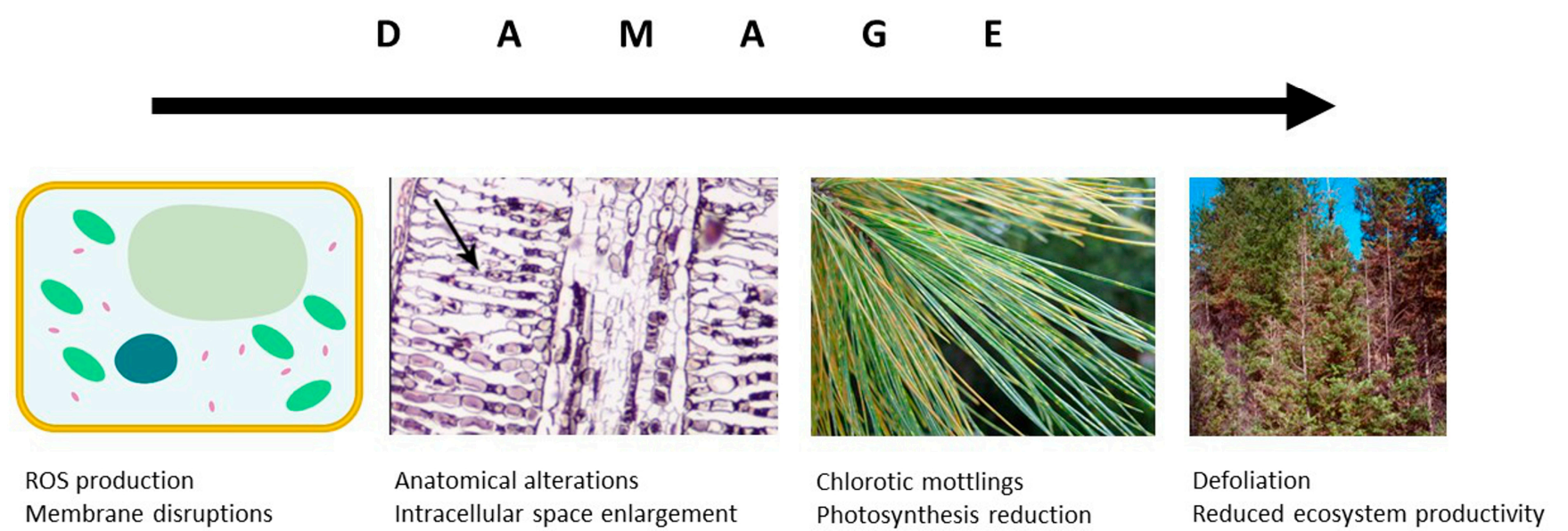

Figure 3. Damaging $\mathrm{O}_{3}$ effects at the cellular and leaf levels influence the carbon allocation at tree and ecosystem level. 
However, $\mathrm{O}_{3}$ may affect carbon uptake at various physiological levels. Exposure to chronic $\left[\mathrm{O}_{3}\right]$ closes stomatal pores leading thus to a reduced stomatal conductance to $\mathrm{CO}_{2}$ diffusion and consequently to a reduced photosynthetic $\mathrm{CO}_{2}$ assimilation [102]. Moreover, $\mathrm{O}_{3}$ reduces photosynthetic $\mathrm{CO}_{2}$ uptake via reduced Rubisco (ribulose-1,5-bisphosphate carboxylase/oxygenase) content $[103,104]$. These effects need to be related to growth and carbon economy at the ecosystem level. In a six-year free-air fumigation at a German forest, Matyssek et al. [105] reported a 44\% decline in stem productivity in Fagus sylvatica exposed to twice-ambient $\left[\mathrm{O}_{3}\right]$. Reductions in biomass accumulation have been associated with a modified carbon allocation to plant organs. Based on the meta-analysis of temperate and boreal forests of the northern hemisphere, Wittig et al. [106] reported a significant decrease of the root-to-shoot ratio under elevated $\left[\mathrm{O}_{3}\right]$ indicating greater sensitivity of root biomass to $\left[\mathrm{O}_{3}\right] . \mathrm{O}_{3}$-induced reduction in root surface area per soil volume unit [107] can result in decreases of water and nutrition uptakes. Investigation of carbon pools revealed faster $\mathrm{O}_{3}$-induced turnover of leaves/needles, reduction of canopy carbon pools and a substantial increase in carbon deposited to the forest floor [108].

Several metrics have been developed to assess the effect of $\mathrm{O}_{3}$ on plants and to relate threshold $\left[\mathrm{O}_{3}\right]$ to relative yield loss. For example, the index AOT40 (accumulated dose of ozone over a threshold of $40 \mathrm{ppbv}$ ), which has to be interpreted with regional and meteorological aspect, has been established. This index is calculated over the sunlight hours and whole growing season, which is being prolonged towards a larger number of days in line with earlier phenological phase occurrence $[109,110]$. The highest and lowest AOT40 values are reported from Mediterranean regions $(38,359 \mathrm{ppb}$ h) and Northern Europe (5094 ppb h), respectively. In Continental Central Europe, AOT40 ranges between 13,636 and 23,515 ppb h, while it is 8207-13,751 ppb h in Atlantic Central Europe [35]. However, this AOT40 index takes into account only of $\mathrm{O}_{3}$ exposure, but not the physiological properties enabling $\mathrm{O}_{3}$ diffusion to plant tissues, which is directly responsible for the damage. Therefore, an alternative index based on stomatal $\mathrm{O}_{3}$ uptake, $\mathrm{POD}_{Y}$ (phytotoxic $\mathrm{O}_{3}$ dose above a flux threshold of $\mathrm{Y} n \mathrm{nmol} \mathrm{O}_{3} \mathrm{~m}^{-2} \mathrm{~s}^{-1}$ ) has also been advanced. The threshold is species-specific and depends on the detoxifying capacity of the plant (e.g., [111]). The value of $Y$ ranges from 7 in Alnus glutinosa to $0-1 \mathrm{nmol} \mathrm{O}_{3} \mathrm{~m}^{-2} \mathrm{~s}^{-1}$ in Fagus sylvatica. The minimum values of $\mathrm{POD}_{0}$ were found in Northern Europe $\left(14 \mathrm{mmol} \mathrm{m}^{-2}\right.$ year $\left.^{-1}\right)$, while maximum values of 29.7-32.1 mmol m${ }^{-2}$ year $^{-1}$ were observed in Mediterranean and Atlantic regions of Europe [35].

While PODY is mainly used in scientific and modelling studies, AOT40 still prevails in legislation (European Council Directive 2008/50/EC) and monitoring activities [112]. Protection of vegetation recommended by UNECE [113] sets an exposure-based critical level of AOT40 as $5000 \mathrm{ppbv}$ h. Attitudes may change, and POD $_{\mathrm{Y}}$ is now being discussed as a potential integral part of new legislation in Europe [114]. While AOT40 decreased and $\mathrm{POD}_{0}$ increase in Lithuanian forests over the period 2007-2014 [115], Klingberg et al. [116] reported a reduction of both indices in Picea abies at EMEP sites. More recently, Karlsson et al. [117] confirmed a reduction in AOT40 but did not find a change in $\mathrm{POD}_{1}$ for the same tree species. Between 2000 and 2014, AOT40 decreased in most of the European countries (except rural northern areas of Iceland, Svalbard and Sweden), while $\mathrm{POD}_{0}$ increased from 0.03 to $1.06 \mathrm{mmol} \mathrm{O}_{3} \mathrm{~m}^{-2}$ year ${ }^{-1}$ across Europe [35]. However, in warm and dry years, AOT40 increased [118] and POD $_{Y}$ decreased [119] when compared to wet seasons. To correctly determine the long-term trends in the development of these indices, continual time series over several decades are, therefore, very much needed.

Recently, a new flux-based index combining stomatal exposure and crown defoliation has been determined to define critical levels (CLef) for forest protection against $\mathrm{O}_{3}$-induced visible injuries. Sicard et al. [120] recommended CLef to be less than $5 \mathrm{mmol} \mathrm{m}^{-2}$ year ${ }^{-1} \mathrm{POD}_{1}$ for broadleaved species and less than $12 \mathrm{mmol} \mathrm{m}^{-2}$ year ${ }^{-1} \mathrm{POD}_{1}$ for conifers. CLef representing $\geq 25 \%$ of crown defoliation is recommended to be maximal 17,000 and $19,000 \mathrm{ppbv}$ h of AOT40 for conifers and broadleaved species, respectively. It is obvious that those new indices are inevitably linked to PODY and AOT40 and only new limits are set. 
As the injuries induced by $\mathrm{O}_{3}$ deposition on cuticle are usually small [82], the negative effect of $\mathrm{O}_{3}$ uptake is connected mainly to stomatal $\mathrm{O}_{3}$ flux. The total flux of ozone to vegetation may be thought of as two components: stomatal flux (uptake through the stomatal pores) and non-stomatal flux (deposition to other surfaces in the canopy and also reaction with gaseous compounds in the canopy air-space). The ratio between stomatal and total $\mathrm{O}_{3}$ flux depends on actual microclimatic conditions and differs in various ecosystems (Table 1). The highest seasonal maxima of total $\mathrm{O}_{3}$ flux were recorded in Quercus ilex forest [119] followed by Populus grandidentata [121], Larix decidua and Pinus halepensis [122,123]. Daily mean values range from $0.8 \mathrm{nmol} \mathrm{m}^{-2} \mathrm{~s}^{-1}$ in Pinus sylvestris forest in Belgium [92] to $8.6 \mathrm{nmol} \mathrm{m}^{-2} \mathrm{~s}^{-1}$ in Q. ilex forest in Italy. See Table 1 for more details. Stomatal flux is determined by $\left[\mathrm{O}_{3}\right]$ and two resistances connected in series (leaf boundary layer resistance and the stomatal resistance). While boundary layer resistance depends on wind speed and heat flux, stomatal resistance is primarily influenced by irradiance and VPD [86]. Stomatal $\mathrm{O}_{3}$ flux was found to be $37 \%$ of total $\mathrm{O}_{3}$ flux in a northern mixed hardwood forest [121], but it was $21 \%$ in semi-arid regions of Israel [122], and only $15 \%$ in Larix decidua, Alps, Italy [123]. However, in subalpine coniferous forest dominated by Engelmann spruce (Picea engelmannii) and subalpine fir (Abies lasiocarpa) in southern Wyoming, USA, $59 \%$ of stomatal $\mathrm{O}_{3}$ flux was found as an annual average [81]. Similarly, stomatal $\mathrm{O}_{3}$ flux dominated in Czech P. abies mountainous forest under moderately cool and humid climate [124]. Juráň et al. [29] found that stomatal flux represents $53.5 \%$ of total $\mathrm{O}_{3}$ flux during summer days with partly-cloudy conditions, but it decreases to $43.5 \%$ during sunny days. Moreover, a fraction of stomatal $\mathrm{O}_{3}$ flux could be further modulated by forest age $[124,125]$. Comparison of modelled and measured fluxes could be found elsewhere [29]. See Table 1 for more details.

Non-stomatal $\mathrm{O}_{3}$ flux includes deposition onto the soil, stems and branches, cuticles and any external surface present. Chemical $\mathrm{O}_{3}$ sink also contributes to non-stomatal flux involving the reactions of $\mathrm{O}_{3}$ molecules with VOCs, $\mathrm{NO}$ and aerosols. Non-stomatal flux dominates in spring and summer because of the exponential increase of VOC concentration with increasing air temperature and solar radiation $[126,127]$. It is the period, when $\left[\mathrm{O}_{3}\right]$ is usually the highest. Contrary to that, non-stomatal fluxes are negligible over the winter in temperate forests due to low VOC emissions to the atmosphere [128]. They were significant even at a moorland site in Scotland, without the complications of complex forest canopies: the non-stomatal $\mathrm{O}_{3}$ flux was up to $70 \%$ of the total flux [77]. These findings suggest that most of $\mathrm{O}_{3}$ deposits on leaf cuticles and/or wet layer of the moss, below the sparse herbaceous canopy.

Here we summarise the effects of $\mathrm{O}_{3}$ on NEP (net ecosystem productivity) and GPP (gross primary productivity) in several forest ecosystems estimated by eddy-covariance technique and modelling approaches (Table 2). The impacts of $\mathrm{O}_{3}$ are very diverse. There is no effect in mature Belgian Scots pine forest on GPP measured over 15 years, although critical levels of AOT40 and $\mathrm{POD}_{1}$ were exceeded in each year of measurement [85]. Similarly, in a poplar stand, Belgium, no effect on NEP was reported [129], even though stomatal $\mathrm{O}_{3}$ flux amounted up to $59 \%$ of the total $\mathrm{O}_{3}$ flux. On the other hand, a reduction of NEP was reported in Czech [124] and Swiss forests [130], particularly in Norway spruce and European beech stands. After 20 years of monitoring, the only mild effects of $\mathrm{O}_{3}$ on GPP and photosynthesis were observed in a broad-leaf Harvard forest. These findings were attributed to the fact that $40 \%$ of photosynthesis occurs lower in the canopy, in shade, where stomatal conductance and $\left[\mathrm{O}_{3}\right]$ are lower [131]. So the canopy structure can also modulate the effect of $\mathrm{O}_{3}$. 


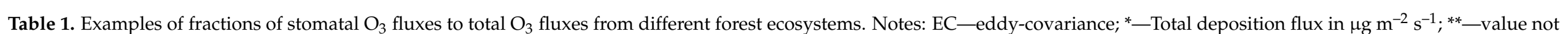
specified.

\begin{tabular}{|c|c|c|c|c|c|c|}
\hline Forest Type & Species & Country & Total Deposition Flux $\left(\mathrm{nmol} \mathrm{m}^{-2} \mathrm{~s}^{-1}\right)$ & Stomatal Flux (\% of Total) & Approach & Reference \\
\hline Subalpine coniferous & $\begin{array}{l}\text { Picea engelmannii } \\
\text { and Abies lasiocarpa }\end{array}$ & Wyoming, USA & $0.5-0.6 *$ (summer max $)$ & 59 & $\mathrm{EC}$ & [81] \\
\hline Mountainous & Picea abies & Czech Republic & 7.09 (daily mean) & dominant $* *$ & modelling & [124] \\
\hline $\begin{array}{l}\text { Northern mixed } \\
\text { hardwood }\end{array}$ & Populus grandidentata & Michigan, USA & 27.7 (seasonal max) & 37 & $\mathrm{EC}$ & [121] \\
\hline $\begin{array}{c}\text { Evergreen } \\
\text { Mediterranean }\end{array}$ & Quercus ilex & Italy & $\begin{array}{c}\text { 6.9-8.6 (daily average) } \\
51 \text { (seasonal max) }\end{array}$ & 34.4 & $\mathrm{EC}$ & [119] \\
\hline Coniferous & Pinus sylvestris & Belgium & $0.8-5.8$ (daily mean) & 26 & modelling & {$[92]$} \\
\hline Coniferous & Picea abies & Denmark & $0.5 *(5$-years mean $)$ & 21 & modelling & [125] \\
\hline Coniferous & Pinus halepensis & Israel & 5-10 (seasonal range) & 21 & EC & [122] \\
\hline Alpine & Larix decidua & Italy & 40 (summer daily max) & 15 & $\mathrm{EC}$ & [123] \\
\hline
\end{tabular}


Generally, a strong correlation of GPP to AOT40 index was shown [132]. Among others, a tight linear decrease of whole-plant dry mass with increasing daylight AOT40 was found in Japanese larch (Larix kaempferi) and beech (Fagus crenata) seedlings [133]. Comparing to the preindustrial era, a reduction of $1-16 \%$ of GPP was reported for USA vegetation covers [134]. Similarly, Karlsson [135] reported a reduction of living biomass stock due to $\mathrm{O}_{3}$ to be $2 \%$ in northern European countries but up to $32 \%$ in central European countries [136]. One of the highest, as much as $24.8 \%$, reduction rates of NEP were for a Norway spruce forest [28] with the highest decrease in July, the warmest month of the year.

Wang et al. [137] modelled biomass carbon stock over 500 years involving a successional series of the temperate deciduous forests. No change of carbon stock was reported due to the change of forest species over the time period with the increasing dominance of isoprene-emitting species. Isoprene acts as a shielding agent preventing $\mathrm{O}_{3}$ to enter the stomatal aperture-isoprene outside of the leaf reacts with $\mathrm{O}_{3}$ [138]. It is clear, that $\mathrm{O}_{3}$ was not an issue for half a millennium, however, it shows a possible direction of how natural ecosystems might possibly evolve and adapt in a $\mathrm{O}_{3}$-rich world by a mechanism incorporating successional dynamics.

Table 2. Effects of $\mathrm{O}_{3}$ on various carbon-related criterion. GPP—gross primary production, NEE—net ecosystem exchange, $\mathrm{NEP}-$ net ecosystem productivity.

\begin{tabular}{|c|c|c|c|c|c|}
\hline Type of Ecosystem & Dominant Plant & $\mathrm{O}_{3}$ Effect & Country & Criterion & Reference \\
\hline Mature stand & Scots pine & neutral & Belgium & GPP & [92] \\
\hline Plantation & mix of poplars & neutral & Belgium & NEE & [129] \\
\hline $\begin{array}{l}\text { Mature stand } \\
\text { Mixed }\end{array}$ & Stone pine & neutral & Italy & GPP & [85] \\
\hline $\begin{array}{l}\text { hardwood/conifer } \\
\text { forests }\end{array}$ & Red oak, Red maple & negligible & USA & GPP & [131] \\
\hline USA vegetation & - & reduction $1-16 \%$ & USA & GPP & [135] \\
\hline Young stand & Norway spruce & reduction & Czech Republic & NEP & [124] \\
\hline Young stand & Norway spruce & reduction $24.8 \%$ & Czech Republic & NEP & [28] \\
\hline Young stand & Ponderosa pine & reduction $12 \%$ & USA & GPP & [85] \\
\hline Orchard & Orange orchard & reduction $19 \%$ & USA & GPP & [85] \\
\hline $\begin{array}{l}\text { Flux sites in Europe } \\
\text { and USA }\end{array}$ & (1) & $\begin{array}{c}\text { reduction } 6-29 \% \text { deciduous forest } \\
\text { reduction } 4-20 \% \text { evergreen } \\
\text { needle leaf forest }\end{array}$ & Europe, USA & biomass & [136] \\
\hline
\end{tabular}

\section{Interactive Effects of $\mathrm{O}_{3}$}

As mentioned above, $\mathrm{O}_{3}$ triggers the generation and accumulation of $\mathrm{H}_{2} \mathrm{O}_{2}$ and / or superoxide, i.e., ROS inducing cell death, depending on the species, accession and cultivar [139]. However, the importance of constitutive (i.e., genetic) protection of plants against $\mathrm{O}_{3}$ remains unclear [140] and is thought to be relatively small as compared to the environmentally induced $\mathrm{O}_{3}$ protection and acclimation adjustment. Accordingly, the high variability of observed plant/ecosystem responses to $\mathrm{O}_{3}$ reported in Table 2 is likely to be due to interactive effects of other co-occurring environmental factors. Here we summarise the potential interactive effects of enhanced $\left[\mathrm{O}_{3}\right]$ with solar radiation, temperature, drought and nitrogen supply (Figure 4), particularly on tree species and forest canopies. These factors are among those found to have the greatest potential to modulate $\mathrm{O}_{3}$ fluxes [141]. However, we do not address the issue of the interactive effect of elevated $\left[\mathrm{O}_{3}\right]$ and $\left[\mathrm{CO}_{2}\right]$ concentrations in this review. This interaction is important and deserves a detailed analysis [89] but it is beyond the scope of the present review. 


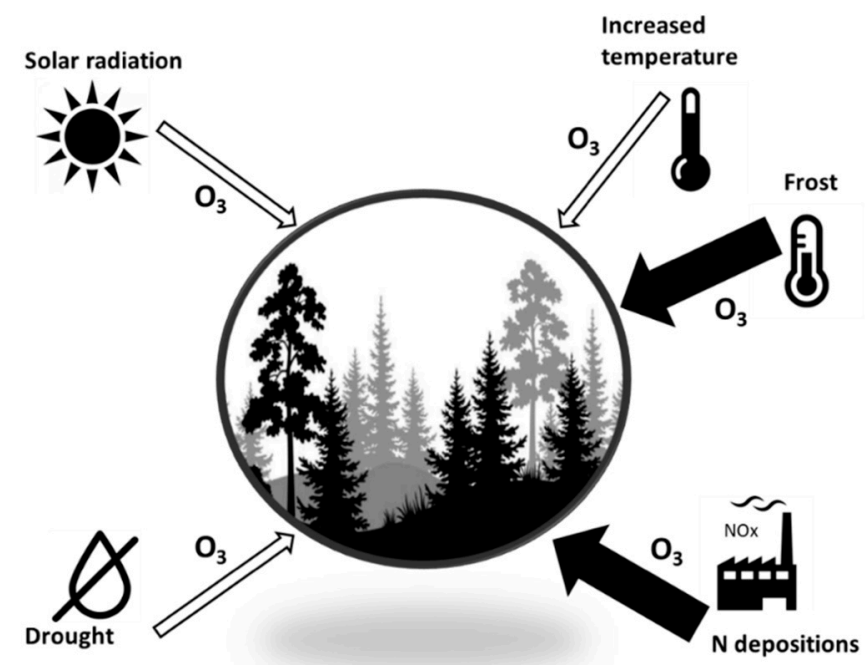

Figure 4. The scheme of potential interactive effects of $\mathrm{O}_{3}$ and other environmental factors. Thin open arrows indicate an amelioration of negative $\mathrm{O}_{3}$ effects; thick dark arrows indicate an enhancement of $\mathrm{O}_{3}$ effects on plants/trees.

\subsection{Interactive Effects of Solar Radiation and $\mathrm{O}_{3}$}

Because of the light attenuation, leaves develop differently in upper and lower regions of dense canopies. Sun- and shade-acclimated leaves are formed. Tjoelker et al. [142] reported higher $\mathrm{O}_{3}$ sensitivity of shade leaves compared with sun leaves of sugar maple (Acer saccharum) exposed to twice-ambient $\left[\mathrm{O}_{3}\right]$. Shade leaves, compared to sun leaves, had greater proportional reductions in light-saturated rate of $\mathrm{CO}_{2}$ uptake associated with strong decreases in chlorophyll content and apparent quantum efficiency. Similarly, high $\left[\mathrm{O}_{3}\right]$ reduced height growth of tomato plants (Lycopersicon esculentum) grown at low irradiances, whereas it had negligible, or a stimulating, effect at high irradiances [143]. It is particularly true at high relative air humidity, typical for deep inside the canopy, stimulating the negative effects of $\mathrm{O}_{3}$. Such variability of ozone sensitivity along the vertical canopy gradients has substantial consequences for the modelling of carbon gain [142,144].

Several studies have also investigated the effect of light spectral composition, particularly the combined effect of shortwave ultraviolet (UV) radiation and high $\left[\mathrm{O}_{3}\right]$ typical for high elevations (Figure 1). Generally, it has been shown that low, ecologically relevant doses of UV-B radiation ameliorate the detrimental effects of $\mathrm{O}_{3}$. Studies of evergreen tree species, Norway spruce and Scots pine, under twice-ambient $\left[\mathrm{O}_{3}\right]$ showed a development of chlorotic mottling with a reduction of photosynthetic capacity and carboxylation efficiency at near zero UV-B, but not at natural UV-B intensities [145]. Such findings indicate an important role of UV radiation in the activation of numerous protective mechanisms and enhancing plant resistance [146] including an accumulation of antioxidants [147] and flavonoids in plant tissues [148] among others.

\subsection{Interactive Effects of Temperature and $\mathrm{O}_{3}$}

In the previous experiments, combined effects of $\mathrm{O}_{3}$ with enhanced air temperatures above the ambient as well as chilling temperatures were studied (Figure 4). The experiments with silver birch (Betula pendula) under boreal conditions have shown that temperature-stimulated growth and carbon allocation in tree biomass is counteracted by simultaneous harmful effects of $\mathrm{O}_{3}$ [149]. While elevated $\left[\mathrm{O}_{3}\right](1.2 \times$ ambient $)$ accelerated leaf senescence, it was delayed by a temperature increase (ambient $\left.+1.2{ }^{\circ} \mathrm{C}\right)$. However, under the combination treatment $\mathrm{O}_{3}$ substantially reduced the temperature effect. Such responses led to an increase of photosynthetic (foliage biomass) to non-photosynthetic (woody biomass) tissue ratio under elevated temperature, but it decreases under $\mathrm{O}_{3}$ and combined treatments. An antagonistic interactive effect of $\mathrm{O}_{3}$ and temperature was also 
found on the thickness of abaxial epidermis of European aspen (Populus tremula). While leaves exposed to elevated $\left[\mathrm{O}_{3}\right]$ had significantly thicker adaxial epidermis, elevated temperature reduced the impact of $\mathrm{O}_{3}[150]$.

At the leaf level, in silver birch (Betula pendula) and European aspen (Populus tremula), a negative $\mathrm{O}_{3}$ effect on $\mathrm{CO}_{2}$ assimilation rate was partly compensated by the elevated temperature demonstrating an interactive effect of both the treatments [151]. Similarly, an interactive effect on intrinsic water use efficiency (iWUE), defined as the ratio between $\mathrm{CO}_{2}$ assimilation rate and stomatal conductance, was observed when elevated $\left[\mathrm{O}_{3}\right]$ reduced the stimulatory effect of elevated temperature on iWUE. Such interaction was statistically significant in B. pendula, but not in P. tremula.

Metabolomic analyses did not reveal any interactive effects of elevated temperature and $\left[\mathrm{O}_{3}\right]$ on most metabolites and metabolic pathways [152]. Nevertheless, combined treatment of these factors led to an enhanced content of amino acids, intermediates of citric acid cycle and some carbohydrates as well as $\gamma$-aminobutyric acid (GABA) compared to individual $\mathrm{O}_{3}$ treatment. These compounds are often associated with plant stress response and/or play a role of signalling molecules under environmental stresses [153]. Such plasticity of the plant metabolome ensures no alteration in the seedlings' sensitivity to autumn and spring frosts as demonstrated by the temperature required for $50 \%$ lethality [152].

Under natural conditions, enhanced temperatures are often associated with enhanced VPD values having a substantial effect on the openness of stomata $[154,155]$ and consequently on stomatal $\mathrm{O}_{3}$ flux $[28,29]$. Accordingly, lower stomatal $\mathrm{O}_{3}$ fluxes and lower $\mathrm{O}_{3}$-induced injuries may be observed in warm Mediterranean conditions than in the cooler boreal and temperate forest ecosystems [156-158].

Although winter $\mathrm{O}_{3}$ fluxes into the forest ecosystems are relatively small compared to the summer fluxes [29], evergreen urban trees/forests in particular may be subjected to elevated $\left[\mathrm{O}_{3}\right]$ episodes in parallel to chilling, freezing and/or winter desiccation. Barnes et al. [159] investigated this topic using pea (Pisum sativum) as a model plant species. They found an amplification of freezing injury under elevated $\left[\mathrm{O}_{3}\right]$, including greater electrolyte leakage, that resulted in the deactivation of photochemical reactions of photosynthesis. Although these results are difficult to apply to woody plants that are well-adapted to winter conditions, these experiments revealed greater damage in pea cultivars with a slow stomatal closure under elevated $\left[\mathrm{O}_{3}\right]$ and having thus a greater $\mathrm{O}_{3}$ flux in the internal leaf tissues.

Later research focused particularly on the interactive effects of elevated $\left[\mathrm{O}_{3}\right]$ and spring frost events $[160,161]$. While ozone $(1.3 \times$ ambient $)$ exacerbated the effect of frost (applied after bud burst) only on diameter increment of Silver birch (Betula pendula), interactive effects on a number of physiological variables, including photochemical quantum yield of photosystem II, photochemical quenching of absorbed light energy and chlorophyll and carotenoid contents, were observed [149]. These findings lead to the conclusion that combined exposure to elevated $\left[\mathrm{O}_{3}\right]$ and frost appears to damage tree saplings more than a single stress. In contrary, no increase in freeze-induced damage of overwintering birch buds was reported under elevated $\left[\mathrm{O}_{3}\right]$ [161]. This is likely to be associated with an increased ratio of raffinose to sucrose and the transcript levels of the dehydrin gene. On the other hand, alterations in carbohydrate metabolism of buds is highly genome-specific and more work is needed [161].

\subsection{Interactive Effect of Drought and $\mathrm{O}_{3}$}

Periods with high tropospheric $\left[\mathrm{O}_{3}\right]$ are often associated with hot and dry summers. Increased frequency, intensity and duration of such conditions are predicted in the future [162]. Accordingly, it is very likely that many tree species and forest stands are, and will be, simultaneously exposed to enhanced $\left[\mathrm{O}_{3}\right]$ and insufficient water supply. Some experiments have fortuitously coincided with naturally occurring drought. Matyssek et al. [70] describe a highly comprehensive free air experiment on adult beech (Fagus sylvatica) lasting five years, which included the extreme drought of 2003. Drought-induced stomatal closure decoupled the uptake of $\mathrm{O}_{3}$ from $\left[\mathrm{O}_{3}\right]$, i.e., stomatal closure conferred a protective effect. 
No significant interaction of $\mathrm{O}_{3}$ and drought was detected in the growth and leaf traits of Japanese beech (Fagus crenata) during the first growing season, but significant interactive effects on photosynthesis were found in the second growing season $[163,164]$ indicating thus the importance of the stress duration. Limited water supply induced amelioration of the negative $\mathrm{O}_{3}$ effects due to a reduced stomatal $\mathrm{O}_{3}$ flux caused by reduced leaf water potential and stomatal conductance under the drought conditions [165]. Similarly, reduced stomatal $\mathrm{O}_{3}$ fluxes were observed in coniferous Norway spruce (Picea abies) under the periods of low soil humidity $[29,166]$.

Metabolomic studies have shown that drought activates the pathways from glucose to xylulose, xylose, inositol and several polyols and sugar alcohols [153]. Polyols, such as sorbitol and mannitol, act as osmoprotectants and protectants of thiol-regulated enzymes involved in deactivation of free radicals, such as hydroxyl radicals. These biochemical adjustments, together with an accumulation of gluthatione antioxidant under limited soil water content [164], contribute to plant cross-tolerance against other oxidative stresses. Soil drought, and even more in combination with ozone, enhanced pools of ascorbate, lutein and xanthophylls in Norway spruce needles [167]. Together with an increased epoxidation status of the xanthophyll cycle, an increased antioxidant capacity in plants is suggested. Accordingly, antagonistic effects of $\mathrm{O}_{3}$ and drought on leaf photosynthetic traits are mostly reported in both broadleaved $[163,168]$ and coniferous [169] tree species. However, antagonistic effects of $\mathrm{O}_{3}$ and water stress on the growth are rare [170] and are mostly additive $[171,172]$. In conclusion, drought stress reduces but does not protect tree species from injurious $\mathrm{O}_{3}$ impacts on growth and physiological processes associated with carbon assimilation [173,174]. Most recently, Xu et al. [175] have shown that limited water availability does not protect poplar saplings from $\mathrm{O}_{3}$-induced reduction of water use efficiency.

Modelling studies across diverse environmental conditions in Europe [156,158] have shown that the arid conditions of South-European regions result in reduced stomatal conductance and consequent lower stomatal $\mathrm{O}_{3}$ fluxes irrespective of the high AOT40s that prevail in these regions. Together with an enhanced stimulation of protective mechanisms against ROS [153] injuries of Mediterranean tree species are less than those in trees grown under the conditions of temperate and/or boreal zones [144,158].

\subsection{Interactive Effect of Nitrogen Supply and $\mathrm{O}_{3}$}

Nitrogen availability is a limiting factor of forest production, particularly in $\mathrm{N}$-poor boreal ecosystems (reviewed in Högberg et al. [176]); however, excessive nitrogen deposition may lead to the imbalance between carbon and nitrogen in plant tissues having consequent negative effects on total content of phenolic compounds [177]. A meta-analysis study [178] revealed increased concentrations of phenolics and terpenes in response to elevated $\left[\mathrm{O}_{3}\right]$. Angiosperms were found to be more responsive than gymnosperms. Such acclimation consequently resulted in reduced insect herbivore activity. Insufficient amounts of phenolics under excessive nitrogen availability may lead, in contrast, to increased sensitivity of plants to abiotic and biotic stresses and consequently to reduced plant growth and development as shown in the case of Scots pine (Pinus sylvestris; [179]). On the other hand, reduced nitrogen availability may increase plant sensitivity to $\mathrm{O}_{3}$ because of the insufficient catalytic activities of enzymes involved in defence processes [153,180]. However, the reported findings on interactive effects of elevated $\left[\mathrm{O}_{3}\right]$ and nitrogen supply are inconsistent.

No interactive effect of nitrogen availability on stomatal $\mathrm{O}_{3}$ flux and biomass production was reported in birch (Betula pendula) grown under a boreal environment [181], evergreen broadleaf camphorwood (Cinnamomum camphora) grown under sub-tropical regions [182] or Quercus serrata, C. sieboldii, P. densiflora and C. japonica seedlings grown under temperate conditions (summarised in Watanabe et al. [164]). On the other hand, significant interactions of $\mathrm{O}_{3}$ and nitrogen load on dry-biomass increments were found in F. crenata and L. kaempferi [164] enhancing the $\mathrm{O}_{3}$ sensitivity of trees with increasing nitrogen supply. Similarly, Marzuoli et al. [183] showed that increased wet N-deposition 
triggers negative $\mathrm{O}_{3}$ effects on biomass formation of young European hornbeam trees (Carpinus betulus). Also, Handley and Grulke [184] reported greater decline in photosynthetic capacity, defined as the $\mathrm{CO}_{2}$ assimilation rate at saturating light intensity and $\left[\mathrm{CO}_{2}\right]$, in fertilised California black oak (Quercus kelloggii). These findings led to the conclusion that $\mathrm{N}$-fertilisation tend to increase plant sensitivity to $\mathrm{O}_{3}$.

It has been proven that reduced $\mathrm{CO}_{2}$ assimilation rate under conditions of high $\left[\mathrm{O}_{3}\right]$ and nitrogen supply is rather caused by reduced allocation of nitrogen to soluble proteins, including the Rubisco enzyme, while nitrogen content per unit leaf area, stomatal conductance as well as mesophyll conductance to $\mathrm{CO}_{2}$ diffusion remain unchanged $[185,186]$.

The species-specificity in response to the combined effect of elevated $\left[\mathrm{O}_{3}\right]$ and nitrogen supply was reported by Fusaro et al. [187] for two Mediterranean tree species. Nitrogen supply ameliorated the harmful effects of $\mathrm{O}_{3}$ in deciduous manna ash (Fraxinus ornus), but not in evergreen holm oak (Quercus ilex). It seems that nitrogen addition particularly increased activities of SOD (superoxide dismutase), CAT (catalase) and GSH (glutathione peroxidase) antioxidative enzymes involved in $\mathrm{O}_{2}{ }^{-}$and $\mathrm{H}_{2} \mathrm{O}_{2}$ scavenging in $F$. ornus, while an alternative antioxidant response such as the emission of volatile organic compounds were preferentially activated in $Q$. ilex. Nevertheless, the activities of these antioxidative enzymes were not significantly influenced in spring wheat plants exposed only to elevated $\left[\mathrm{O}_{3}\right][188]$.

\section{Conclusions}

What have we learned from fifty years of research? Experimental exposure of plants to high concentrations of ozone, or the exposure of plants to charcoal-filtered air, tell us that almost all species so far examined are damaged to some extent by ozone at the concentrations that often prevail in all regions of the world. This inevitably has a huge economic consequence for horticulture, agriculture and forestry, perhaps greater than that of any other pollutant gas [189]. Not all species are equally sensitive, and so the balance of competition between weeds and crops is likely to be altered.

The question of 'how much damage' is more difficult to answer, as the plant response depends not only on the species concerned but also on other stress factors. Drought and the supply of nitrogen are particularly variable across years and sites, and experiments have shown how these can interact with ozone to cause damage levels which can be hard to predict. The first attempts to evaluate the impact of crop losses were the NCLAN (National Crop Loss Assessment Network) in the USA [190] and the European Open Top Chamber Programme [191]. There were many further experiments in Asia. Feng and Kobashi [192] performed a meta-analysis of available data for key crops. The percentage crop losses were: potatoes 5.3 , barley 8.9 , wheat 9.7 , rice 17.5 , beans 19 and soybeans 7.7 . These are probably still the best overall assessments we have of the overall ozone damage to crops. Ozone may well become a threat to food security as the $\mathrm{O}_{3}$ precursors $\mathrm{NO}_{x}$ and VOCs increase further due to human activities.

As we have seen in Section 4, the interaction of ozone with other environmental variables is often highly significant but varies with species and climatology; thus it is hard to predict and quite challenging to build a framework of regulations based on the concept of dose. In brief, high (non-excessive) irradiances, mild temperature increases and particularly drought tend to ameliorate negative effects of $\mathrm{O}_{3}$ on plant physiology and growth, whereas freezing temperatures and high nitrogen deposition may increase plant sensitivity to $\mathrm{O}_{3}$. Most recent studies discovered also the potential of $\mathrm{O}_{3}$ to modulate the colonisation of roots by arbuscular mycorrhizal fungi [193] and herbivores attacks [194] —-topics worth to be further investigate in trees.

For forests, the question of 'how much damage?' is harder to answer as the older work has been done on seedlings which may not be good surrogates for mature trees [71,106,195,196]. In some cases, tree seedlings and saplings have shown up to $40 \%$ less growth in ambient $\mathrm{O}_{3}$ than when in charcoal filtered air [106]. FACE experiments have enabled limited enrichment experimentations on mature trees but the number of experimental units and the number of trees is inevitably rather small. Consequently, the statistical power of such experiments is low 
(see [197]). Long-term eddy-covariance, coupled to models, may be the way forward (see Section 2.3). The technology is well-developed and the limitations of the technique have been widely discussed [198]. Forest ecosystems are of special concern, because of the risk to the global carbon sink and the biodiversity that forests contain.

Author Contributions: Conceptualisation, S.J. and O.U.; data curation, S.J.; writing-original draft preparation, S.J., J.G., O.U.; writing-review and editing, J.G.; visualisation, S.J., O.U.; project administration, O.U. All authors have read and agreed to the published version of the manuscript.

Funding: This work was supported by the Ministry of Education, Youth and Sports of the Czech Republic within the project "SustES-Adaptation strategies for sustainable ecosystem services and food security under adverse environmental conditions" (CZ.02. 1.01/0.0/0.0/16_019/0000797).

Data Availability Statement: Data is contained within the article.

Acknowledgments: This work was supported by the Ministry of Education, Youth and Sports of the Czech Republic within the project "SustES-Adaptation strategies for sustainable ecosystem services and food security under adverse environmental conditions" (CZ.02. 1.01/0.0/0.0/16_019/0000797).

Conflicts of Interest: The authors declare no conflict of interest.

\section{References}

1. Granier, C.; Bessagnet, B.; Bond, T.; D’Angiola, A.; van der Gon, H.D.; Frost, G.J.; Heil, A.; Kaiser, J.W.; Kinne, S.; Klimont, Z.; et al. Evolution of anthropogenic and biomass burning emissions of air pollutants at global and regional scales during the 1980-2010 period. Clim. Chang. 2011, 109, 163. [CrossRef]

2. Parrish, D.D.; Lamarque, J.-F.; Naik, V.; Horowitz, L.; Shindell, D.T.; Staehelin, J.; Derwent, R.; Cooper, O.R.; Tanimoto, H.; Volz-Thomas, A.; et al. Long-term changes in lower tropospheric baseline ozone concentrations: Comparing chemistry-climate models and observations at northern midlatitudes. J. Geophys. Res. 2014, 119, 5719-5736. [CrossRef]

3. Royal Society. Ground-Level Ozone in the 21st Century: Future Trends, Impacts and Policy Implications; The Royal Society: London, UK, 2008; ISBN 978-0-85403-713-1.

4. Cooper, O.R.; Parrish, D.D.; Ziemke, J.; Balashov, N.V.; Cupeiro, M.; Galbally, I.E.; Gilge, S.; Horowitz, L.; Jensen, N.R.; Lamarque, J.-F.; et al. Global distribution and trends of tropospheric ozone: An observation- based review. Elementa 2014, $2,000029$. [CrossRef]

5. Archibald, A.T.; Turnock, S.T.; Griffiths, P.T.; Cox, T.; Derwent, R.G.; Knote, C.; Shin, M. On the changes in surface ozone over the twenty-first century: Sensitivity to changes in surface temperature and chemical mechanisms. Phil. Trans. R. Soc. 2020, 378, 20190329. [CrossRef]

6. Luwe, M.; Heber, U. Ozone detoxification in the apoplasm and symplasm of spinach, broad bean and beech leaves at ambient and elevated concentrations of ozone in air. Planta 1995, 197, 448-455. [CrossRef]

7. Wieser, G.; Matyssek, R. Linking ozone uptake and defense towards a mechanistic risk assessment for forest trees. New Phytol. 2007, 174, 7-9. [CrossRef]

8. Volz, A.; Kley, D. Evaluation of the Montsouris series of ozone measurements made in the nineteenth century. Nature 1988, 332, 240-242. [CrossRef]

9. Marenco, A.; Gouget, H.; Nédélec, P.; Pagés, J.-P. Evidence of a long-term increase in tropospheric ozone from Pic du Midi series: Consequences: Positive radiative forcing. J. Geophys. Res. 1994, 99, 16617-16632. [CrossRef]

10. Warmbt, W. Luftchemische Untersuchungen des bodennahen Ozons 1952-1964: Methoden und Ergebnisse; Abhandlungen des Meteorologischen Dienstes der Deutschen Demokratischen Republick Nr 72 [Band X]; Akademie-Verlag: Berlin, Germany, 1964.

11. Haagen-Smit, A.J. Chemistry and physiology of Los Angeles smog. Ind. Eng. Chem. Res. 1952, 44, 1342-1346. [CrossRef]

12. Tingey, D.; Hogsett, W.; Lee, E.; Laurence, J.A. Stricter ozone ambient air quality standard has beneficial effect on ponderosa pine in California. Environ. Manag. 2004, 34, 397-405. [CrossRef]

13. Lee, E.H.; Tingey, D.T.; Hogsett, W.E.; Laurence, J.A. History of tropospheric ozone for the San Bernardino Mountains of Southern California, 1963-1999. Atmos. Environ. 2003, 37, 2705-2717. [CrossRef]

14. Chang, K.-L.; Petropavlovskikh, I.; Cooper, O.R.; Schultz, M.G.; Wang, T. Regional trend analysis of surface ozone observations from monitoring networks in eastern North America, Europe and East Asia. Elementa 2017, 5, 50. [CrossRef]

15. Gaudel, A.; Cooper, O.R.; Ancellet, G.; Barret, B.; Boynard, A.; Burrows, J.P.; Clerbaux, C.; Coheur, P.-F.; Cuesta, J.; Cuevas, E.; et al. Tropospheric ozone assessment report: Present-day distribution and trends of tropospheric ozone relevant to climate and global atmospheric chemistry model evaluation. Elementa 2018, 6, 39. [CrossRef]

16. Zhang, Q.; Yuan, B.; Shao, M.; Wang, X.; Lu, S.; Lu, K.; Wang, M.; Chen, L.; Chang, C.-C.; Liu, S.C. Variations of ground-level O 3 and its precursors in Beijing in summertime between 2005 and 2011. Atmos. Chem. Phys. 2014, 14, 6089-6101. [CrossRef]

17. Li, J.F.; Lu, K.; Lv, W.; Li, J.; Zhong, L.; Ou, Y.; Chen, D.; Huang, X.; Zhang, Y. Fast increasing of surface ozone concentrations in Pearl River Delta characterized by a regional air quality monitoring network during 2006-2011. J. Environ. Sci. 2014, 26, 23-36. [CrossRef] 
18. Fu, Y.; Liao, H. Simulation of the interannual variations of biogenic emissions of volatile organic compounds in China: Impacts on tropospheric ozone and secondary organic aerosol. Atmos. Environ. 2012, 59, 170-185. [CrossRef]

19. Zhang, X.; Du, J.; Zhang, L.; Huang, T.; Gao, H.; Mao, X.; Ma, J. Impact of afforestation on surface ozone in the North China Plain during the three-decade period. Agric. For. Meteorol. 2020, 287, 107979. [CrossRef]

20. Lu, X.; Zhang, L.; Zhao, Y.; Jacob, D.J.; Hu, Y.; Hu, L.; Gao, M.; Liu, X.; Petropavlovskikh, I.; McClure-Begley, A.; et al. Surface and tropospheric ozone trends in the Southern Hemisphere since 1990: Possible linkages to poleward expansion of the Hadley circulation. Sci. Bull. 2019, 64, 400-409. [CrossRef]

21. Anet, J.G.; Steinbacher, M.; Gallardo, L.; Velásquez Álvarez, P.A.; Emmenegger, L.; Buchmann, B. Surface ozone in the Southern Hemisphere: 20 years of data from a site with a unique setting in El Tololo, Chile. Atmos. Chem. Phys. 2017, 17, 6477-6492. [CrossRef]

22. Xu, J.; Huang, X.; Wang, N.; Li, Y.; Ding, A. Understanding ozone pollution in the Yangtze River Delta of eastern China from the perspective of diurnal cycles. Sci. Total. Environ. 2021, 752, 141928. [CrossRef]

23. Calfapietra, C.; Fares, S.; Manes, F.; Morani, A.; Sgrigna, G.; Loreto, F. Role of Biogenic Volatile Organic Compounds (BVOC) emitted by urban trees on ozone concentration in cities: A review. Environ. Pollut. 2013, 183, 71-80. [CrossRef] [PubMed]

24. Young, P.J.; Archibald, A.T.; Bowman, K.W.; Lamarque, J.-F.; Naik, V.; Stevenson, D.S.; Tilmes, S.; Voulgarakis, A.; Wild, O.; Bergmann, D.; et al. Pre-industrial to end 21st century projections of tropospheric ozone from the Atmospheric Chemistry and Climate Model Intercomparison Project (ACCMIP). Atmos. Chem. Phys 2013, 13, 2063-2090. [CrossRef]

25. Akimoto, H. Global air quality and pollution. Science 2003, 302, 1716-1719. [CrossRef] [PubMed]

26. Logan, J.A. Tropospheric ozone: Seasonal behavior, trends, and anthropogenic influence. J. Geophys. Res. 1985, 90, 10463-10482. [CrossRef]

27. Monks, P.S. A review of the observations and origins of the spring ozone maximum. Atmos. Environ. 2000, 34, 3545-3561. [CrossRef]

28. Juráň, S.; Edwards-Jonášová, M.; Cudlín, P.; Zapletal, M.; Šigut, L.; Grace, J.; Urban, O. Prediction of ozone effects on net ecosystem production of Norway spruce forest. iForest 2018, 11, 743-750. [CrossRef]

29. Juráň, S.; Šigut, L.; Holub, P.; Fares, S.; Klem, K.; Grace, J.; Urban, O. Ozone flux and ozone deposition in a mountain spruce forest are modulated by sky conditions. Sci. Total. Environ. 2019, 672, 296-304. [CrossRef]

30. Hůnová, I.; Brabec, M.; Malý, M. Trends in ambient $\mathrm{O}_{3}$ concentrations at twelve sites in the Czech Republic over the past three decades: Close inspection of development. Sci. Total. Environ. 2020, 746, 141038. [CrossRef]

31. Tang, G.; Wang, Y.; Li, X.; Ji, D.; Hsu, S.; Gao, X. Spatial-temporal variations in surface ozone in Northern China as observed during 2009-2010 and possible implications for future air quality control strategies. Atmos. Chem. Phys. 2012, 12, $2757-2776$. [CrossRef]

32. Ding, A.J.; Fu, C.B.; Yang, X.Q.; Sun, J.N.; Zheng, L.F.; Xie, Y.N.; Herrmann, E.; Nie, W.; Petäjä, T.; Kerminen, V.-M.; et al. Ozone and fine particle in the western Yangtze River Delta: An overview of $1 \mathrm{yr}$ data at the SORPES station. Atmos. Chem. Phys. 2013, 13, 5813-5830. [CrossRef]

33. Jiang, J.; Aksoyoglu, S.; Ciarelli, G.; Baltensperger, U.; Prévôt, A.S.H. Changes in ozone and PM2.5 in Europe during the period of 1990-2030: Role of reductions in land and ship emissions. Sci. Total. Environ. 2020, 741, 140467. [CrossRef] [PubMed]

34. Parrish, D.D.; Law, K.S.; Staehelin, J.; Derwent, R.; Cooper, O.R.; Tanimoto, H.; Volz-Thomas, A.; Gilge, S.; Scheel, H.-E.; Steinbacher, M.; et al. Long-term changes in lower tropospheric baseline ozone concentrations at northern mid-latitudes. Atmos. Chem. Phys. 2012, 12, 11485-11504. [CrossRef]

35. Proietti, C.; Fornasier, M.F.; Sicard, P.; Anav, A.; Paoletti, E.; De Marco, A. Trends in tropospheric ozone concentrations and forest impact metrics in Europe over the time period 2000-2014. J. For. Res. 2020. [CrossRef]

36. Oltmans, S.J.; Lefohn, A.S.; Shadwick, D.; Harris, J.M.; Scheel, H.E.; Galbally, I.; Tarasick, D.W.; Johnosn, B.J.; Brunke, E.-G.; Claude, H. Recent tropospheric ozone changes-A pattern dominated by slow or no growth. Atmos. Environ. 2013, 67, 331-351. [CrossRef]

37. Thompson, A.M.; Balashov, N.V.; Witte, J.C.; Coetzee, J.G.R.; Thouret, V.; Posny, F. Tropospheric ozone increases over the southern Africa region: Bellwether for rapid growth in Southern Hemisphere pollution? Atmos. Chem. Phys. 2014, 14, 9855-9869. [CrossRef]

38. Staehelin, J.; Tummon, F.; Revell, L.; Stenke, A.; Peter, T. Tropospheric ozone at northern mid-latitudes: Modeled and measured long-term changes. Atmosphere 2017, 8, 163. [CrossRef]

39. Menser, H.A.; Heggestad, H.E.; Street, O.E. Responses of plants to air pollutants 2. Effects of ozone concentrations and leaf maturity to Nicotiana tabacum. Phytopathology 1963, 53, 1304-1308.

40. Bell, J.N.B.; Cox, R.A. Atmospheric ozone and plant damage in United Kingdom. Environ. Pollut. 1975, 8, 163-170. [CrossRef]

41. Lewis, E.; Brennan, E. Disparity in ozone response of bean plants grown in a greenhouse, growth chamber or open-top chamber. J. Air Pollut. Control Assoc. 1977, 27, 889-891. [CrossRef]

42. Heagle, A.S.; Body, D.E.; Heck, W.W. An open-top field chamber to assess the impact of air pollution on plants. J. Environ. Qual. 1973, 365-368. [CrossRef]

43. Mandle, R.H.; Weinstein, L.H.; Keveny, M. A cylindrical open-top chamber for the exposure of plants to air pollutants in the field. J. Environ. Qual. 1973, 371-376. [CrossRef]

44. Allen, L.H.; Drake, B.G., Jr.; Rogers, H.H.; Shinn, J.H. Field techniques for exposure of plants and ecosystems to elevated $\mathrm{CO}_{2}$ and other trace gases. CRC Crit. Rev. Plant Sci. 1992, 11, 85-119. [CrossRef] 
45. D'Andrea, L.; Rinaldi, M. Systems to evaluate the effects of atmospheric $\mathrm{CO}_{2}$ concentrations on field crops: A review of open top chambers. Ital. J. Agrometeorol. 2010, 15, 23-234.

46. Welshofer, K.B.; Zarnetske, P.L.; Lany, N.K.; Thompson, L.A.E. Open-top chambers for temperature manipulation in taller-stature plant communities. Methods Ecol. Evol. 2018, 9, 254-259. [CrossRef]

47. Boeck, H.D.; Lemmens, C.M.H.M.; Bossuyt, H.; Malchair, S.; Carnol, M.; Merckx, R.; Nijs, I.; Ceulemans, R. How do climate warming and plant species richness affect water use in experimental grasslands? Plant Soil 2006, 288, 249-261. [CrossRef]

48. Davis, J.M.; Rogers, H.H. Wind tunnel testing of open top field chambers for plant effects assessment. J. Air Pollut. Control Assoc. 1980, 30, 905-908. [CrossRef]

49. Baldocchi, D.D.; White, R.; Johnston, J.W. A wind-tunnel study to design large open-top chambers for whole-tree pollutant exposure experiments. J. Air Waste Manag. Assoc. 1989, 39, 1549-1556. [CrossRef]

50. Unsworth, M.H.; Heagle, A.S.; Heck, W.W. Gas-exchange in open-top field chambers 1. Measurement and analysis of atmospheric resistances to gas exchange. Atmos. Environ. 1984, 18, 373-380. [CrossRef]

51. Heagle, A.S.; Philbeck, R.B.; Rogers, H.H.; Letchworth, H.H. Dispensing and monitoring ozone in open-top field chambers for plant-effects studies. Phytopathology 1979, 69, 15-20. [CrossRef]

52. Unsworth, M.H.; Lesser, V.M.; Heagle, A.S. Radiation interception and the growth of soybeans exposed to ozone in open-top field chambers. J. Appl. Ecol. 1984, 21, 1059-1079. [CrossRef]

53. Wiltshire, J.J.J.; Wright, C.J.; Unsworth, M.H. A new method for exposing mature trees to ozone episodes. For. Ecol. Manag. 1992, 51, 115-120. [CrossRef]

54. Drake, B.G.; Leadley, P.W.; Arp, W.J.; Nassiry, D.; Curtis, P.S. An open-top chamber for field studies of elevated atmospheric $\mathrm{CO}_{2}$ concentration on saltmarsh vegetation. Funct. Ecol. 1982, 3, 363-371. [CrossRef]

55. Peng, J.; Xu, Y.; Shang, B.; Laiye, Q.; Feng, Z. Impact of nitrogen fertilization management during maize (Zea mays L.) production. Environ. Pollut. 2020, 266, 115158. [CrossRef] [PubMed]

56. Ashmore, M.R.; Ainsworth, N. The effects of ozone and cutting on the species composition of artificial plant communities. Funct. Ecol. 1995, 9, 708-712. [CrossRef]

57. Ghosh, A.; Pandey, P.; Agrawal, M.; Agrawal, S.B. Interactive effects and competitive shift between Triticum aestivum L. (wheat) and Chenopodium album L. (fat-hen) under ambient and elevated ozone. Environ. Pollut. 2020, 265, 114764. [CrossRef] [PubMed]

58. Li, P.; Yin, R.; Shang, B.; Agathokleous, E.; Zhou, H.; Feng, Z. Interactive effects of ozone exposure and nitrogen addition on tree root traits and biomass allocation pattern: An experimental case study and literature meta-analysis. Sci. Total Environ. 2020, 710, 136379. [CrossRef] [PubMed]

59. McLeod, A.R.; Baker, C.K. The use of open field systems to assess yield response to gaseous pollutants. In Assessment of Crop Loss from Air Pollutants; Heck, W.W., Taylor, O.C., Tingey, D.T., Eds.; Springer: Dordrecht, The Netherlands, 1988. [CrossRef]

60. Hendrey, G.R.; Lewin, K.F.; Kolber, Z.; Evans, L.S. Controlled enrichment system for experimental fumigation of plants in the field with sulfur dioxide. J. Air Waste Manag. Assoc. 1992, 42, 1324-1327. [CrossRef]

61. McLeod, A.R.; Long, S.P. Free air carbon dioxide enrichment (FACE) in global change research: A review. Adv. Ecol. Res. 1999, 28, 1-56. [CrossRef]

62. Isebrands, J.G.; McDonald, E.P.; Kruger, E.; Hendrey, G.; Percy, K.; Pregitzer, K.; Sober, J.; Karnosky, D.F. Growth responses of Populus tremuloides clones to interacting elevated carbon dioxide and tropospheric ozone. Environ. Pollut. 2001, 115, 359-371. [CrossRef]

63. Erbs, M.; Fangmeier, A. A chamberless field exposure system for ozone enrichment of short vegetation. Environ. Pollut. 2005, 133, 91-102. [CrossRef]

64. Tang, H.; Liu, G.; Han, Y.; Zhu, J.; Kobyashi, K. A system for free-air ozone concentration elevation with rice and wheat: Control performance and ozone exposure regime. Atmos. Environ. 2011, 45, 6276-6282. [CrossRef]

65. Bernacchi, C.J.; Leakey, A.D.B.; Heady, L.E.; Morgan, P.B.; Dohleman, F.G.; McGrath, J.M.; Gillespie, K.M.; Wittig, V.E.; Rogers, A.; Long, S.P.; et al. Hourly and seasonal variation in photosynthesis and stomatal conductance of soybean grown at future $\mathrm{CO}_{2}$ and ozone concentrations for 3 years under fully open-air field conditions. Plant Cell Environ. 2006, 29, 2077-2090. [CrossRef] [PubMed]

66. Paoletti, E.; Materassi, A.; Fasano, G.; Hoshika, Y.; Carriero, G.; Silaghi, D.; Badea, O. A new-generation 3D ozone FACE (Free Air Controlled Exposure). Sci. Total Environ. 2017, 575, 1407-1414. [CrossRef] [PubMed]

67. Hart, K.M.; Curioni, G.; Blaen, P.; Harper, N.J.; Miles, P.; Lewin, K.F.; Nagy, J.; Bannister, E.J.; Cai, X.M.; Thomas, R.M.; et al. Characteristics of free air carbon dioxide enrichment of a northern temperate forest. Glob. Chang. Biol. 2019, 26, $1023-1037$. [CrossRef] [PubMed]

68. Talhelm, A.F.; Pregitzer, K.S.; Kubiske, M.E.; Zak, D.R.; Campany, C.E.; Burton, A.J.; Dickson, R.E.; Hendrey, G.R.; Isebrands, J.G.; Lewin, K.F.; et al. Elevated carbon dioxide and ozone alter productivity and ecosystem carbon content in northern temperate forests. Glob. Chang. Biol. 2014, 20, 2492-2504. [CrossRef]

69. Hoshika, Y.; Watanabe, M.; Kitao, M.; Häberle, K.-H.; Grams, T.E.E.; Koike, T.; Matyssek, R. Ozone induces stomatal narrowing in European and Siebold's beeches: A comparison between two experiments of free-air ozone exposure. Environ. Pollut. 2015, 196, 527-533. [CrossRef]

70. Matyssek, R.; Bytnerowicz, A.; Karlsson, P.E.; Paoletti, E.; Sanz, M.; Schaub, M.; Wieser, G. Promoting the $\mathrm{O}_{3}$ flux concept for European forest trees. Environ. Pollut. 2007, 146, 587-607. [CrossRef] 
71. Kelly, J.M.; Samuelson, L.; Edwards, G.; Hanson, P.; Kelting, D.; Mays, A.; Wullschleger, S. Are seedlings reasonable surrogates for trees? An analysis of ozone impacts on Quercus rubra. Water Air Soil Pollut. 1995, 85, 1317-1324. [CrossRef]

72. Eastman, J.A.; Stedman, D.H. A fast-response sensor for ozone eddy-correlation flux measurement. Atmos. Environ. 1977, 11, 1209-1211. [CrossRef]

73. Wesely, M.L.; Eastman, J.A.; Cook, D.R.; Hicks, B.B. Daytime variation of ozone eddy fluxes to maize. Bound. Layer Meteorol. 1978, 15, 361-373. [CrossRef]

74. Baldocchi, D.D.; Meyers, T. On using eco-physiological, micrometeorological and biogeochemical theory to evaluate carbon dioxide, water vapor and trace gas fluxes over vegetation. Agric. For. Meteorol. 1988, 90, 1-25. [CrossRef]

75. Baldocchi, D.; Falge, E.; Gu, L.; Olson, R.; Hollinger, D.; Running, S.; Anthoni, P.; Bernhofer, C.; Davis, K.; Evans, R.; et al. FLUXNET: A new tool to study the temporal and spatial variability of ecosystem-scale carbon dioxide, water vapor, and energy flux densities. Bull. Am. Meteorol. Soc. 2011, 82, 2415-2434. [CrossRef]

76. Rebmann, C.; Aubinet, M.; Hape, S.; Arriga, N.; Aurela, M.; Burba, G.; Clement, R.; De Ligne, A.; Fratini, G.; Gielen, B.; et al. ICOS eddy covariance flux-station setup: A review. Int. Agrophys. 2018, 32, 471-494. [CrossRef]

77. Fowler, D.; Flechard, C.; Cape, J.N.; Storeton-West, R.L.; Coyle, M. Measurements of ozone deposition to vegetation quantifying the flux, the stomatal and non-stomatal components. Water Air Soil Pollut. 2001, 130, 63-74. [CrossRef]

78. Rannik, U.; Altimir, N.; Mammarella, L.; Bäck, J.; Rinne, J.; Ruuskanen, T.N.; Hari, P.; Vesala, T.; Kulmala, M. Ozone deposition into boreal forest over a decade of observations: Evaluating deposition partitioning and driving variables. Atmos. Chem. Phys. 2012, 12, 12165-12182. [CrossRef]

79. Fares, S.; Conte, A.; Chabbi, A. Ozone flux in plant ecosystems: New opportunities for long-term monitoring networks to deliver ozone-risk assessments. Environ. Sci. Pollut. Res. 2018, 25, 8240-8248. [CrossRef]

80. Tuovinen, J.P.; Aurelia, M.; Laurila, T. Resistences to ozone deposition to a flark fen in the northern aapa mire zone. J. Geophys. Res. Atmos. 1998, 103, 16953-16966. [CrossRef]

81. Zeller, K.F.; Nikolov, N.T. Quantifying simultaneous fluxes of ozone, carbon dioxide and water vapor above a subalpine forest ecosystem. Environ. Pollut. 2000, 107, 1-20. [CrossRef]

82. Fares, S.; Weber, R.; Park, J.; Gentner, D.; Karlik, J.; Goldstein, A.H. Ozone deposition to an orange orchard: Partitioning between stomatal and non-stomatal sinks. Environ. Pollut. 2012, 169, 258-266. [CrossRef]

83. Stella, P.; Personne, E.; Lamaud, E.; Loubet, B.; Trebs, I.; Cellier, P. Assessment of the total, stomatal, cuticular, and soil 2 year ozone budgets of an agricultural field with winter wheat and maize crops. J. Geophys. Res. Biogeosci. 2013, 118, 1120-1132. [CrossRef]

84. Wieser, G.; Havranek, W.M. Ozone uptake in the sun and shade crown of spruce-Quantifying the physiological effects of ozone exposure. Trees 1993, 7, 227-232. [CrossRef]

85. Fares, S.; Vargas, R.; Detto, M.; Goldstein, A.H.; Karlik, J.; Paoletti, E.; Vitale, M. Tropospheric ozone reduces carbon assimilation in trees: Estimates from analysis of continuous flux measurements. Glob. Chang. Biol. 2013, 19, 2427-2443. [CrossRef] [PubMed]

86. Monteith, J.L.; Unsworth, M.H. Principles of Environmental Physics; Edward Arnold: London, UK, 1973 ; ISBN 0713123753.

87. Sellers, P.J.; Tucker, C.J.; Collatz, G.J. A revised land surface parameterization (SIB2) for atmospheric GCMs II.The generation of global fields of terrestrial biophysical parameters from satellite data. J. Clim. 1996, 9, 707-737. [CrossRef]

88. Massman, W.J. Toward an ozone standard to protect vegetation based on effective dose: A review of deposition resistances and a possible metric. Atmos. Environ. 2004, 38, 2323-2337. [CrossRef]

89. Oliver, R.J.; Mercado, L.M.; Sitch, S.; Simpson, D.; Medlyn, B.E.; Lin, Y.-S.; Folberth, G.A. Large but decreasing effect of ozone on the European carbon sink. Biogeosciences 2018, 15, 4245-4269. [CrossRef]

90. Savi, F.; Nemitz, E.; Coyle, M.; Aitkenhead, M.; Frumau, K.; Gerosa, G.; Finco, A.; Gruening, C.; Godet, I.; Loubet, B.; et al. Neural network analysis to evaluate ozone damage to vegetation under different climatic conditions. Front. For. Glob. Chang. 2020, 3, 42. [CrossRef]

91. Papale, D.; Valentini, R. A new assessment of European forests carbon exchanges by eddy fluxes and artificial neural network spatialization. Glob. Chang. Biol. 2003, 9, 525-535. [CrossRef]

92. Verryckt, L.T.; Op De Beeck, M.; Neirynck, J.; Gielen, B.; Roland, M.; Janssens, I.A. No impact of tropospheric ozone on the gross primary productivity of a Belgian pine forest. Biogeosciences 2017, 14, 1839-1855. [CrossRef]

93. Briegel, F.; Lee, S.C.; Black, T.A.; Jassal, R.S.; Christen, A. Factors controlling long-term carbon dioxide exchange between a Douglas-fir stand and the atmosphere identified using an artificial neural network approach. Ecol. Modell. 2020, 435, 109266. [CrossRef]

94. Lawrence, D.M.; Fisher, R.A.; Koven, C.D.; Oleson, K.W.; Swenson, S.C.; Bonan, G.; Colier, N.; Ghimire, B.; van Kampenhout, L.; Kennedy, D.; et al. The Community Land Model version 5: Description of new features, benchmarking, and impact of forcing uncertainty. J. Adv. Model. Earth Syst. 2019, 11, 4245-4287. [CrossRef]

95. Clifton, O.; Fiore, A.M.; Massman, W.J.; Baublitz, C.B.; Coyle, M.; Emberson, L.; Fares, S.; Farmer, D.K.; Gentine, P.; Gerosa, G.; et al. Dry deposition of ozone over land: Processes, measurement, and modeling. Rev. Geophys. 2020, 58, e2019RG000670. [CrossRef]

96. Dizengremel, P.; Thiec, D.L.; Bagard, M.; Jolivet, Y. Ozone risk assessment for plants: Central role of metabolism-dependent changes in reducing power. Environ. Pollut. 2008, 156, 11-15. [CrossRef] [PubMed] 
97. Zapletal, M.; Juráň, S.; Krpeš, V.; Michna, K.; Edwars-Jonášová, M.; Cudlín, P. Effect of ozone flux on selected structural and antioxidant characteristics of a mountain norway spruce forest. Balt. For. 2018, 24, 261-267.

98. Pellegrini, E.; Hoshika, Y.; Dusart, N.; Cotrozzi, L.; Gérard, J.; Nali, C.; Vaultier, M.-N.; Jolivet, Y.; Lorenzini, G.; Paoletti, E. Antioxidative responses of three oak species under ozone and water stress conditions. Sci. Total Environ. 2019, 647, 390-399. [CrossRef] [PubMed]

99. Jolivet, Y.; Bagard, M.; Cabané, M.; Vaultier, M.-N.; Gandin, A.; Afif, D.; Dizengremel, P.; Le Thiec, D. Deciphering the ozoneinduced changes in cellular processes: A prerequisite for ozone risk assessment at the tree and forest levels. Ann. For. Sci. 2016, 73, 923-943. [CrossRef]

100. Kivimäenpää, M.; Sutinen, S.; Calatayud, V.; Sanz, M.J. Visible and microscopic needle alterations of mature Aleppo pine (Pinus halepensis) trees growing on an ozone gradient in eastern Spain. Tree Physiol. 2010, 30, 541-554. [CrossRef]

101. Vollenweider, P.; Woodcock, H.; Kelty, M.; Hofer, R.-M. Reduction of stem growth and site dependency of leaf injury in Massachusetts black cherries exhibiting ozone symptoms. Environ. Pollut. 2003, 125, 467-480. [CrossRef]

102. Sitch, S.; Cox, P.; Collins, W.; Huntingford, C. Indirect radiative forcing of climate change through ozone effects on the land-carbon sink. Nature 2007, 448, 791-794. [CrossRef]

103. Ainsworth, E.A.; Yendrek, C.R.; Sitch, S.; Collins, W.J.; Emberson, L.D. The effects of tropospheric ozone on net primary productivity and implications for climate change. Ann. Rev. Plant Biol. 2012, 63, 637-661. [CrossRef]

104. Wittig, V.E.; Ainsworth, E.A.; Long, S.P. To what extent do current and projected increases in surface ozone affect photosynthesis and stomatal conductance of trees? A meta-analytic review of the last 3 decades of experiments. Plant Cell Environ. 2007, 30, 1150-1162. [CrossRef]

105. Matyssek, R.; Wieser, G.; Ceulemans, R.; Rennenberg, H.; Pretzsch, H.; Haberer, K.; Löw, M.; Nunn, A.J.; Werner, H.; Wipfler, P.; et al. Enhanced ozone strongly reduces carbon sink strength of adult beech (Fagus sylvatica)—Resume from the free-air fumigation study at Kranzberg Forest. Environ. Pollut. 2010, 158, 2527-2532. [CrossRef] [PubMed]

106. Wittig, V.E.; Ainsworth, E.A.; Naidu, S.L.; Karnosky, D.F.; Long, S.P. Quantifying the impact of current and future tropospheric ozone on tree biomass, growth, physiology and biochemistry: A quantitative meta-analysis. Glob. Chang. Biol. 2009, 15, 396-424. [CrossRef]

107. Mrak, T.; Eler, K.; Badea, O.; Hoshika, Y.; Carrari, E.; Paoletti, E.; Kraigher, H. Elevated ozone prevents acquisition of available nitrogen due to smaller root surface area in poplar. Plant Soil 2020, 450, 585-599. [CrossRef]

108. Arbaugh, M.J.; Miller, P.R.; Carroll, J.J.; Takemoto, B.; Procter, T. Relationships of ozone exposure to pine injury in the Sierra Nevada and San Bernardino Mountains of California, USA. Environ. Pollut. 1998, 101, 291-301. [CrossRef]

109. Anav, A.; De Marco, A.; Friedlingstein, P.; Savi, F.; Sicard, P.; Sitch, S.; Vitale, M.; Paoletti, E. Growing season extension affects ozone uptake by European forests. Sci. Total Environ. 2019, 669, 1043-1052. [CrossRef]

110. Nezval, O.; Krejza, J.; Světlík, J.; Šigut, L.; Horáček, P. Comparison of traditional ground-based observations and digital remote sensing of phenological transitions in a floodplain forest. Agric. For. Meteorol. 2020, 291, 108079. [CrossRef]

111. Hoshika, Y.; Carrari, E.; Mariotti, B.; Martini, S.; De Marco, A.; Sicard, P.; Paoletti, E. Flux-based ozone risk assessment for a Plant Injury Index (PII) in three european cool-temperate deciduous tree species. Forests 2020, 11, 82. [CrossRef]

112. Hůnová, I. Ambient air quality in the Czech republic: Past and present. Atmosphere 2020, 11, 214. [CrossRef]

113. UNECE, United Nations Economic Commission for Europe. Mapping Critical Levels for Vegetation. Manual on Methodologies and Criteria for Modelling and Mapping Critical Loads $\mathcal{E}$ Levels and Air Pollution Effects, Risks and Trends; United Nations Economic Commission for Europe (UNECE) Convention on Long Range Transboundary Air Pollution: Geneva, Switzerland, 2010.

114. Paoletti, E.; Alivernini, A.; Anav, A.; Badea, O.; Carrari, E.; Chivulescu, S.; Conte, A.; Ciriani, M.L.; Dalstein-Richier, L.; De Marco, A.; et al. Toward stomatal-flux based forest protection against ozone: The MOTTLES approach. Sci. Total Environ. 2019, 691, 516-527. [CrossRef]

115. Araminienè, V.; Sicard, P.; Anav, A.; Agathokleous, E.; Stakènas, V.; De Marco, A.; Varnagirytė-Kabašinskienė, I.; Paoletti, E.; Girgždienè, R. Trends and inter-relationships of ground-level ozone metrics and forest health in Lithuania. Sci. Total Environ. 2019, 658, 1265-1277. [CrossRef]

116. Klingberg, J.; Engardt, M.; Karlsson, P.E.; Langner, J.; Pleijel, H. Declining ozone exposure of European vegetation under climate change and reduced precursor emissions. Biogeosciences 2014, 11, 5269-5283. [CrossRef]

117. Karlsson, P.E.; Klingberg, J.; Engardt, M.; Andersson, C.; Langner, J.; Karlsson, G.P.; Pleijel, H. Past, present and future concentrations of ground-level ozone and potential impacts on ecosystems and human health in northern Europe. Sci. Total Environ. 2017, 576, 22-35. [CrossRef] [PubMed]

118. Hůnová, I.; Schreiberová, M. Ambient ozone phytotoxic potential over the Czech forests as assessed by AOT40. iForest 2012, 5, 153-162. [CrossRef]

119. Gerosa, G.; Vitale, M.; Finco, A.; Manes, F.; Denti, A.B.; Cieslik, S. Ozone uptake by an evergreen Mediterranean Forest (Quercus ilex) in Italy. Part I: Micrometeorological flux measurements and flux partitioning. Atmos. Environ. 2005, 39, 3255-3266. [CrossRef]

120. Sicard, P.; De Marco, A.; Carrari, E.; Dalstein-Richier, L.; Hoshika, Y.; Badea, O.; Pitar, D.; Fares, S.; Conte, A.; Popa, I.; et al. Epidemiological derivation of flux-based critical levels for visible ozone injury in European forests. J. For. Res. 2020, 31, 1509-1519. [CrossRef] 
121. Hogg, A.; Uddling, J.; Ellsworth, D.; Carroll, M.A.; Pressley, S.; Lamb, B.; Vogel, C. Stomatal and non-stomatal fluxes of ozone to a northern mixed hardwood forest. Tellus 2007, 59, 514-525. [CrossRef]

122. Li, Q.; Gabay, M.; Rubin, Y.; Raveh-Rubin, S.; Rohatyn, S.; Tatarinov, F.; Rotenberg, E.; Ramati, E.; Dicken, U.; Preisler, Y.; et al. Investigation of ozone deposition to vegetation under warm and dry conditions near the Eastern Mediterranean coast. Sci. Total Environ. 2019, 658, 1316-1333. [CrossRef]

123. Finco, A.; Marzuoli, R.; Chiesa, M.; Gerosa, G. Ozone risk assessment for an Alpine larch forest in two vegetative seasons with different approaches: Comparison of POD1 and AOT40. Environ. Sci. Pollut. Res. 2017, 24, 26238-26248. [CrossRef]

124. Zapletal, M.; Cudlin, P.; Chroust, P.; Urban, O.; Pokorny, R.; Edwards-Jonasova, M.; Czerny, R.; Janous, D.; Taufarova, K.; Vecera, Z; et al. Ozone flux over a Norway spruce forest and correlation with net ecosystem production. Environ. Pollut. 2011, 159, 1024-1034. [CrossRef]

125. Mikkelsen, T.N.; Ro-Poulsen, H.; Hovmand, M.F.; Jensen, N.O.; Pilegaard, K.; Egeløv, A.H. Five-year measurements of ozone fluxes to a Danish Norway spruce canopy. Atmos. Environ. 2004, 38, 2361-2371. [CrossRef]

126. Tingey, D.; Turner, D.; Weber, J. Factors controlling the emission of monoterpenes and other volatile organic compounds. In Trace Gas Emissions by Plants; Sharkey, T., Mooney, H., Holland, E., Eds.; Academic: San Diego, CA, USA, 1991; ISBN 012639010X.

127. Juráň, S.; Pallozzi, E.; Guidolotti, G.; Fares, S.; Šigut, L.; Calfapietra, C.; Alivernini, A.; Savi, F.; Večeřová, K.; Křůmal, K.; et al. Fluxes of biogenic volatile organic compounds above temperate Norway spruce forest of the Czech Republic. Agric. For. Meteorol. 2017, 232, 500-513. [CrossRef]

128. Fares, S.; McKay, M.; Holzinger, R.; Goldstein, A.H. Ozone fluxes in a Pinus ponderosa ecosystem are dominated by non-stomatal processes: Evidence from long-term continuous measurements. Agric. For. Meteorol. 2010, 150, 420-431. [CrossRef]

129. Zona, D.; Gioli, B.; Fares, S.; De Groote, T.; Pilegaard, K.; Ibrom, A.; Ceulemans, R. Environmental controls on ozone fluxes in a poplar plantation in Western Europe. Environ. Pollut. 2014, 184, 201-210. [CrossRef] [PubMed]

130. Braun, S.; Schindler, C.; Rihm, B. Growth losses in Swiss forests caused by ozone: Epidemiological data analysis of stem increment of Fagus sylvatica L. and Picea abies Karst. Environ. Pollut. 2014, 192, 129-138. [CrossRef] [PubMed]

131. Yue, X.; Keenan, T.F.; Munger, W.; Unger, N. Limited effect of ozone reductions on the 20-year photosynthesis trend at Harvard forest. Glob. Chang. Biol. 2016, 22, 3750-3759. [CrossRef]

132. Holmes, C.D. Air pollution and forest water use. Nature 2014, 507, E1-E2. [CrossRef]

133. Yamaguchi, M.; Watanabe, M.; Matsumura, H.; Kohno, Y.; Izuta, T. Experimental studies on the effects of ozone on growth and photosynthetic activity of japanese forest tree species. Asian J. Atmos. Environ. 2011, 5, 65-78. [CrossRef]

134. Yue, X.; Unger, N. Ozone vegetation damage effects on gross primary productivity in the United States. Atmos. Chem. Phys. 2014, 14, 9137-9153. [CrossRef]

135. Karlsson, P.E. Ozone Impacts on Carbon Sequestration in Northern and Central European Forests; IVL Report B 2065; IVL Swedish Environmental Research Institute: Gothenburg, Sweden, 2012.

136. Ducker, J.A.; Holmes, C.D.; Keenan, T.F.; Fares, S.; Goldstein, A.H.; Mammarella, I.; William Munger, J.; Schnell, J. Synthetic ozone deposition and stomatal uptake at flux tower sites. Biogeosciences 2018, 15, 5395-5413. [CrossRef]

137. Wang, B.; Shugart, H.; Shuman, J.; Lerdau, M.T. Forests and ozone: Productivity, carbon storage and feedbacks. Sci. Rep. 2016, 6, 22133. [CrossRef]

138. Loreto, F.; Velikova, V. Isoprene produced by leaves protects the photosynthetic apparatus against ozone damage, quenches ozone products, and reduces lipid peroxidation of cellular membranes. Plant Physiol. 2001, 127, 1781-1787. [CrossRef]

139. Wohlgemuth, H.; Mittelstrass, K.; Kschieschan, S.; Bender, J.; Weigel, H.J.; Overmyer, K.; Kangasjarvi, J.; Sandermann, H.; Langebartels, C. Activation of an oxidative burst is a general feature of sensitive plants exposed to the air pollutant ozone. Plant Cell Environ. 2002, 25, 717-726. [CrossRef]

140. Calatayud, A.; Alvarado, J.; Barreno, E. Changes in chlorophyll a fluorescence, lipid peroxidation, and detoxificant system in potato plants grown under filtered and non-filtered air in open-top chambers. Photosynthetica 2001, 39, 507-513. [CrossRef]

141. de Vries, W.; Posch, M.; Simpson, D.; Reinds, G.J. Modelling long-term impacts of changes in climate, nitrogen deposition and ozone exposure on carbon sequestration of European forest ecosystems. Sci. Total Environ. 2017, 605-606, 1097-1116. [CrossRef] [PubMed]

142. Tjoelker, M.G.; Volin, J.C.; Oleksyn, J.; Reich, P.B. Interaction of ozone pollution and light effects on photosynthesis in a forest canopy experiment. Plant Cell Environ. 1995, 18, 895-905. [CrossRef]

143. Mortensen, L.M. Effects of ozone concentration on growth of tomato at various light, air humidity and carbon dioxide levels. Sci. Hortic. 1992, 49, 17-24. [CrossRef]

144. Emberson, L. Effects of ozone on agriculture, forests and grasslands. Philos. Trans. Royal Soc. A 2020, 378, 20190327. [CrossRef] [PubMed]

145. Schnitzler, J.P.; Langebartels, C.; Heller, W.; Liu, J.; Lippert, M.; Döhring, T.; Sandermann, H. Ameliorating effect of UV-B radiation on the response of Norway spruce and Scots pine to ambient ozone concentrations. Glob. Chang. Biol. 1999, 5, 83-94. [CrossRef]

146. Jansen, M.A.K.; Bilger, W.; Hideg, É.; Strid, Å.; Aphalo, P.; Brelsford, C.; Klem, K.; Mátai, A.; Llorens, L.; Nezval, J.; et al. Interactive effects of UV-B radiation in a complex environment. Plant Physiol. Biochem. 2019, 134, 1-8. [CrossRef]

147. Baumbusch, L.O.; Eiblmeier, M.; Schnitzler, J.P.; Heller, W.; Sandermann, H., Jr.; Polle, A. Interactive effects of ozone and low UV-B radiation on antioxidants in spruce (Picea abies) and pine (Pinus sylvestris) needles. Physiol. Plant. 1998, 104, 248-254. [CrossRef] 
148. Holub, P.; Nezval, J.; Štroch, M.; Špunda, V.; Urban, O.; Jansen, M.A.K.; Klem, K. Induction of phenolic compounds by UV and PAR is modulated by leaf ontogeny and barley genotype. Plant Physiol. Biochem. 2019, 134, 81-93. [CrossRef] [PubMed]

149. Kasurinen, A.; Biasi, C.; Holopainen, T.; Rousi, M.; Mäenpää, M.; Oksanen, E. Interactive effects of elevated ozone and temperature on carbon allocation of silver birch (Betula pendula) genotypes in an open-air field exposure. Tree Physiol. 2012, 32, 737-751. [CrossRef] [PubMed]

150. Hartikainen, K.; Nerg, A.M.; Kivimäenpää, M.; Kontunen-Soppela, S.; Mäenpää, M.; Oksanen, E.; Rousi, M.; Holopainen, T. Emissions of volatile organic compounds and leaf structural characteristics of European aspen (Populus tremula) grown under elevated ozone and temperature. Tree Physiol. 2009, 29, 1163-1173. [CrossRef]

151. Mäenpää, M.; Riikonen, J.; Kontunen-Soppela, S.; Rousi, M.; Oksanen, E. Vertical profiles reveal impact of ozone and temperature on carbon assimilation of Betula pendula and Populus tremula. Tree Physiol. 2011, 31, 808-818. [CrossRef]

152. Riikonen, J.; Kontunen-Soppela, S.; Ossipov, V.; Tervahauta, A.; Tuomainen, M.; Oksanen, E.; Vapaavuori, E.; Heinonen, J.; Kivimäenpää, M. Needle metabolome, freezing tolerance and gas exchange in Norway spruce seedlings exposed to elevated temperature and ozone concentration. Tree Physiol. 2012, 32, 1102-1112. [CrossRef]

153. Sardans, J.; Gargallo-Garriga, A.; Urban, O.; Klem, K.; Walker, T.W.N.; Holub, P.; Janssens, I.A.; Peñuelas, J. Ecometabolomics for a better understanding of plant responses and acclimation to abiotic factors linked to global change. Metabolites 2020, 10, 239. [CrossRef]

154. Urban, O.; Klem, K.; Ač, A.; Havránková, K.; Holišová, P.; Navrátil, M.; Zitová, M.; Kozlová, K.; Pokorný, R.; Šprtová, M.; et al. Impact of clear and cloudy sky conditions on the vertical distribution of photosynthetic $\mathrm{CO}_{2}$ uptake within a spruce canopy. Funct. Ecol. 2012, 26, 46-55. [CrossRef]

155. Urban, O.; Klem, K.; Holišová, P.; Šigut, L.; Šprtová, M.; Teslová-Navrátilová, P.; Zitová, M.; Špunda, V.; Marek, M.V.; Grace, J. Impact of elevated $\mathrm{CO}_{2}$ concentration on dynamics of leaf photosynthesis in Fagus sylvatica is modulated by sky conditions. Environ. Pollut. 2014, 185, 271-280. [CrossRef]

156. Emberson, L.D.; Ashmore, M.R.; Cambridge, H.M.; Simpson, D.; Tuovinen, J.-P. Modelling stomatal ozone flux across Europe. Environ. Pollut. 2000, 109, 403-413. [CrossRef]

157. Emberson, L.D.; Ashmore, M.R.; Simpson, D.; Tuovinen, J.-P.; Cambridge, H.M. Modelling and mapping ozone deposition in Europe. Water Air Soil Pollut. 2001, 130, 577-582. [CrossRef]

158. Otu-Larbi, F.; Conte, A.; Fares, S.; Wild, O.; Ashworth, K. Current and future impacts of drought and ozone stress on Northern Hemisphere forests. Glob. Chang. Biol. 2020, 26, 6218-6234. [CrossRef] [PubMed]

159. Barnes, J.D.; Reiling, K.; Davison, A.W.; Renner, C.J. Interaction between ozone and winter stress. Environ. Pollut. 1988, 53, $235-254$. [CrossRef]

160. Silfver, T.; Häikiö, E.; Rousi, M.; Holopainen, T.; Oksanen, E. Interactive effects of elevated ozone and springtime frost on growth and physiology of birch (Betula pendula) in field conditions. Trees 2008, 22, 291-301. [CrossRef]

161. Riikonen, J.; Kontunen-Soppela, S.; Vapaavuori, E.; Tervahauta, A.; Tuomainen, M.; Oksanen, E. Carbohydrate concentrations and freezing stress resistance of silver birch buds grown under elevated temperature and ozone. Tree Physiol. 2013, 33, 311-319. [CrossRef] [PubMed]

162. Trnka, M.; Balek, J.; Štepánek, P.; Zahradnícek, P.; Možný, M.; Eitzinger, J.; Žalud, Z.; Formayer, H.; Turna, M.; Nejedlík, P.; et al. Drought trends over part of Central Europe between 1961 and 2014. Clim. Res. 2016, 70, 143-160. [CrossRef]

163. Yonekura, T.; Dokiya, Y.; Fukami, M.; Izuta, T. Effects of ozone and/or soil water stress on growth and photosynthesis of Fagaus crenata seedlings. Water Air Soil Pollut. 2001, 130, 965-970. [CrossRef]

164. Watanabe, M.; Hoshika, Y.; Koike, T.; Izuta, T. Combined effects of ozone and other environmental factors on Japanese trees. In Air Pollution Impacts on Plants in East Asia; Springer: Tokyo, Japan, 2017; pp. 101-110.

165. Flexas, J.; Medrano, H. Energy dissipation in C3 plants under drought. Funct. Plant Biol. 2002, 29, 1209-1215. [CrossRef]

166. Agyei, T.; Juráň, S.; Ofori-Amanfo, K.K.; Šigut, L.; Urban, O.; Marek, M.V. The impact of drought on total ozone flux in a mountain Norway spruce forest. J. For. Sci. 2020, 66, 280-287. [CrossRef]

167. Kronfuß, G.; Polle, A.; Tausz, M.; Havranek, W.M.; Wieser, G. Effects of ozone and mild drought stress on gas exchange, antioxidants and chloroplast pigments in current-year needles of young Norway spruce [Picea abies (L.) Karst.]. Trees 1998, 12, 482-489. [CrossRef]

168. Peron, A.; Kaser, L.; Fitzky, A.C.; Graus, M.; Halbwirth, H.; Greiner, J.; Wohlfahrt, G.; Rewald, B.; Sandén, H.; Karl, T. Combined effects of ozone and drought stress on the emission of biogenic volatile organic compounds from Quercus robur L. Biogeosciences Discuss. 2020. [CrossRef]

169. Inclán, R.; Alonso, R.; Pujadas, M.; Terés, J.; Gimeno, B.S. Ozone and drought stress: Interactive effects on gas exchange in Aleppo pine (Pinus halepensis Mill.). Chemosphere 1998, 36, 685-690. [CrossRef]

170. Gao, F.; Catalayud, V.; Paoletti, E.; Hoshika, Y.; Feng, Z. Water stress mitigates the negative effects of ozone on photosynthesis and biomass in poplar plants. Environ. Pollut. 2017, 230, 268-279. [CrossRef] [PubMed]

171. Shimizu, H.; Ito, S. Combines stress effect on Fagus crenata. For. Sci. 2013, 67, 14-17.

172. Shimizu, H.; Feng, Y.W. Ozone and/or water stress could have influenced the Betula ermanii Cham. forest decline observed at Oku-Nikko, Japan. Environ. Monit. Asses. 2007, 128, 109-119. [CrossRef] [PubMed]

173. Alonso, R.; Elvira, S.; González-Fernández, I.; Calvete, H.; García-Gómez, H.; Bermejo, V. Drought stress does not protect $Q$ uercus ilex L. from ozone effects: Results from a comparative study of two subspecies differing in ozone sensitivity. Plant Biol. 2014, 16, 375-384. [CrossRef] 
174. Li, L.; Manning, W.J.; Tong, L.; Wang, X. Chronic drought stress reduced but not protected Shantung maple (Acer truncatum Bunge) from adverse effects of ozone (O3) on growth and physiology in the suburb of Beijing, China. Environ. Pollut. 2015, $201,34-41$. [CrossRef]

175. Xu, Y.; Feng, Z.; Shang, B.; Yuan, X.; Tarvainen, L. Limited water availability did not protect poplar saplings from water use efficiency reduction under elevated ozone. For. Ecol. Manag. 2020, 462, 117999. [CrossRef]

176. Högberg, P.; Näsholm, T.; Franklin, O.; Högberg, M.N. Tamm review: On the nature of the nitrogen limitation to plant growth in Fennoscandian boreal forests. For. Ecol. Manag. 2017, 403, 161-185. [CrossRef]

177. Påhlsson, A.M.B. Influence of nitrogen fertilization on minerals, carbohydrates, amino acids and phenolic compounds in beech (Fagus sylvatica L.) leaves. Tree Physiol. 1992, 10, 93-100. [CrossRef]

178. Valkama, E.; Koricheva, J.; Oksanen, E. Effects of elevated O3, alone and in combination with elevated $\mathrm{CO}_{2}$, on tree leaf chemistry and insect herbivore performance: A meta-analysis. Glob. Chang. Biol. 2006, 13, 184-201. [CrossRef]

179. Kainulainen, P.; Holopainen, J.K.; Holopainen, T. Combined effects of ozone and nitrogen on secondary compounds, amino acids, and aphid performance in Scots pine. J. Environ. Qual. 2000, 29, 334-342. [CrossRef]

180. Dizengremel, P.; Jolivet, Y.; Tuzet, A.; Ranieri, A.; Le Thiec, D. Integrative leaf-level phytotoxic ozone dose assessment for forest risk modelling. Dev. Environ. Sci. 2013, 13, 267-288. [CrossRef]

181. Dai, L.; Hayes, F.; Sharps, K.; Harmens, H.; Mills, G. Nitrogen availability does not affect ozone flux-effect relationships for biomass in birch (Betula pendula) saplings. Sci. Total Environ. 2019, 660, 1038-1046. [CrossRef]

182. Feng, Z.; Niu, J.; Zhang, W.; Wang, X.; Yao, F.; Tian, Y. Effects of ozone exposure on sub-tropical evergreen Cinnamomum camphora seedlings grown in different nitrogen loads. Trees 2011, 25, 617-625. [CrossRef]

183. Marzuoli, R.; Monga, R.; Finco, A.; Chiesa, M.; Gerosa, G. Increased nitrogen wet deposition triggers negative effects of ozone on the biomass production of Carpinus betulus L. young trees. Environ. Exp. Bot. 2018, 152, 128-136. [CrossRef]

184. Handley, T.; Grulke, N.E. Interactive effects of $\mathrm{O}_{3}$ exposure on California black oak (Quercus kelloggii Newb.) seedlings with and without $\mathrm{N}$ amendment. Environ. Pollut. 2008, 156, 53-60. [CrossRef]

185. Yamaguchi, M.; Watanabe, M.; Iwasaki, M.; Tabe, C.; Matsumura, H.; Kohno, Y.; Izuta, T. Growth and photosynthetic responses of Fagus crenata seedlings to $\mathrm{O} 3$ under different nitrogen loads. Trees 2007, 21, 707-718. [CrossRef]

186. Xu, Y.; Shang, B.; Feng, Z.; Tarvainen, L. Effect of elevated ozone, nitrogen availability and mesophyll conductance on the temperature responses of leaf photosynthetic parameters in poplar. Tree Physiol. 2020, 40, 484-497. [CrossRef]

187. Fusaro, L.; Palma, A.; Salvatori, E.; Basile, A.; Maresca, V.; Asadi Karam, E.; Manes, F. Functional indicators of response mechanisms to nitrogen deposition, ozone, and their interaction in two Mediterranean tree species. PLoS ONE 2017, 12, e0185836. [CrossRef]

188. McKee, I.F.; Eiblmeier, M.; Polle, A. Enhanced ozone-tolerance in wheat grown at an elevated $\mathrm{CO}_{2}$ concentration: Ozone exclusion and detoxification. New Phytol. 2007, 137, 275-284. [CrossRef]

189. Ashmore, M.R.; Marshall, F.M. Ozone impacts on agriculture: An issue of global concern. Adv. Bot. Res. 1998, $29,31-52$. [CrossRef]

190. Heck, W.W.; Cure, W.W.; Rawlings, J.O.; Zaragoza, L.J.; Heagle, A.S.; Heggestad, H.E.; Kohut, R.J.; Kress, L.W.; Temple, P.J. Assessing impacts of ozone on agricultural crops: II. Crop yield functions and alternative exposure statistics. J. Air Pollut. Control Assoc. 1984, 34, 810-817. [CrossRef]

191. Krupa, S.V.; Nosal, M.; Legge, A.H. A numerical analysis of the combined open-top chamber data from the USA and Europe on ambient ozone and negative crop responses. Environ. Pollut. 1998, 101, 157-160. [CrossRef]

192. Feng, Z.; Kobayashi, K. Assessing the impacts of current and future concentrations of surface ozone on crop yield with metaanalysis. Atmos. Environ. 2009, 43, 1510-1519. [CrossRef]

193. Bassin, S.; Blanke, V.; Volk, M.; Fuhrer, J. Ozone and nitrogen effects on juvenile subalpine plants: Complex interactions with species and colonization by arbuscular mycorrhizal fungi (AMF). Water Air Soil Pollut. 2017, 228, 30. [CrossRef]

194. Brosset, A.; Saunier, A.; Kivimäenpää, M.; Blande, J.D. Does ozone exposure affect herbivore-induced plant volatile emissions differently in wild and cultivated plants? Environ. Sci. Pollut. Res. 2020, 27, 1-12. [CrossRef]

195. Broadmeadow, M.S.; Jackson, S.B. Growth responses of Quercus petraea, Fraxinus excelsior and Pinus sylvestris to elevated carbon dioxide, ozone and water supply. New Phytol. 2000, 146, 437-451. [CrossRef]

196. Karnosky, D.F.; Werner, H.; Holopainen, T.; Percy, K.; Oksanen, T.; Oksanen, E.; Heerdt, C.; Fabian, P.; Nagy, J.; Heilman, W.; et al. Free-Air Exposure Systems to scale up ozone research to mature trees. Plant Biol. 2007, 9, 181-190. [CrossRef]

197. Pretzsch, H.; Dieler, J. The dependency of the size-growth relationship of Norway spruce (Picea abies [L.] Karst.) and European beech (Fagus sylvatica [L.]) in forest stands on long-term site conditions, drought events, and ozone stress. Trees Struct. Funct. 2011, 25, 355-369. [CrossRef]

198. Papale, D.; Reichstein, M.; Aubinet, M.; Canfora, E.; Bernhofer, C.; Kutsch, W.; Longdoz, B.; Rambal, S.; Valentini, R.; Vesala, T.; et al. Towards a standardized processing of Net Ecosystem Exchange measured with eddy covariance technique: Algorithms and uncertainty estimation. Biogeosciences 2006, 3, 571-583. [CrossRef] 